\title{
Electron spin resonance (ESR) dating of Quaternary materials
}

\author{
Gerhard Schellmann, Koen Beerten and Ulrich Radtke ${ }^{*}$
}

\begin{abstract}
ESR dating has become an efficient tool in earth sciences for geochronological studies on different kinds of littoral deposits (coral reefs terraces, beach ridge systems, aeolianites) during the last ten years. Improvements in annual dose rate (D') estimation and the newly developed approach for equivalent dose $\left(D_{E}\right)$ determination $\left(D_{E}-D_{\max }\right.$ plot procedure) increase the precision of ESR dating of Holocene and Pleistocene corals as well as marine and terrestrial mollusc shells. This is strongly supported by the comparison of ESR dating results with other numeric dating methods such as radiocarbon and TIMS Uranium series analysis (TIMS ${ }^{230} \mathrm{Th} /{ }^{234} \mathrm{U}$ ). The latter is the main focus of this paper. The uncertainties associated in ESR dating of Holocene corals coincide with the variability of ${ }^{14} \mathrm{C}$ ages caused by the marine reservoir effect. The dating of Pleistocene corals permits the differentiation between the main marine isotope stages (MIS) 5, 7, 9, 11 and 13 as well as between sub-stages $5 \mathrm{e}_{3 / 2}$ and $5 \mathrm{e}_{1}, 5 \mathrm{c}$, and $5 \mathrm{a}_{2}$ and $5 \mathrm{a}_{1}$. The average error range when dating corals is between 5 to $8 \%$. Furthermore, ESR dating of marine and terrestrial mollusc shells has yielded some promising results and permits the differentiation between the interglacial MIS 1, 5, 7 and 9 with an average dating error range of 10 to $15 \%$.

ESR dating of quartz is another promising dating technique for Quaternary and even Neogene geological formations. The presence of quartz in volcanic rocks, tephra, fault gouge and sediments (heated or unheated) allows determining the last time of heating, fault movement or sunlight exposure. Although challenged by several experimental issues, ESR dating of quartz is often the only method able to produce numerical ages for older formations.

ESR has also been applied to a wide variety of other materials such as foraminifera, speleothems, travertines, calcretes and tooth enamel. The most common and reliable application is the ESR dating of mammal teeth, which becomes in conjunction with laser ablation U-series dating, an important method for determining the age of archaeological sites beyond the time range of the ${ }^{14} \mathrm{C}$ dating method back to about 200 to $300 \mathrm{ka}$.
\end{abstract}

\section{[Elektronen Spin Resonanz (ESR)-Datierung quartärer Materialien]}

Kurzfassung: ESR hat sich im letzten Jahrzehnt bei der Datierung verschiedenster littoraler Ablagerungen (Korallenriffterassen, Strandwallsysteme, Dünen) als effizientes Datierungswerkzeug etabliert. Verbesserungen in der Bestimmung der jährlichen Dosisleistung (D') und ein neu entwickelter Ansatz zur Bestimmung der Äquivalent Dosis $\left(D_{E}-D_{\max }\right.$ Verfahren) haben die Präzision der ESR-Datierung sowohl an holozänen und pleistozänen Korallen als auch an marinen und terrestrischen Molluskenschalen verbessert. Dies wurde durch den Vergleich mit anderen numerischen Datierungsverfahren wie Radiokohlenstoff und TIMS-Uranserien-Analyse (TIMS ${ }^{230} \mathrm{Th} /{ }^{234} \mathrm{U}$ ) unterstützt. Der Vergleich mit letzterer Methode steht im Fokus dieses Artikels. Die mit der ESR-Methode verbundenen Ungenauigkeiten bei der Datierung holozäner Korallen liegt in der Größenordnung der Variabilität von ${ }^{14} \mathrm{C}$-Altern, die durch den marinen Reservoireffekt bedingt ist. Die Datierung pleistozäner Korallen erlaubt die Differenzierung der wichtigen marinen Isotopenstadien (MIS) 5 ,

\footnotetext{
*Addresses of authors: G. Schellmann, Universität Bamberg, Lehrstuhl Geographie II - Physische Geographie, Am Kranen 1, D-96045 Bamberg. E-Mail: gerhard.schellmann@ggeo.uni-bamberg.de; K. Beerten, Universität zu Köln, Geographisches Institut, Albertus-Magnus-Platz, D-50923 Köln. E-Mail: kbeerten@unikoeln.de; U. Radtke, Universität zu Köln, Geographisches Institut, Albertus-Magnus-Platz, D-50923 Köln. E-Mail: u.radtke@uni-koeln.de
} 
7, 9,11 und 13 sowie der Untereinheiten $5 \mathrm{e}_{3 / 2}$ und $5 \mathrm{e}_{1}, 5 \mathrm{c}$ und $5 \mathrm{a}_{1}$ und $5 \mathrm{a}_{2}$. Der durchschnittliche Fehler bei der Datierung von Korallen liegt zwischen 5 bis $8 \%$. Weiterhin hat die Datierung mariner und terrestrischer Mollusken mittels ESR viel versprechende Resultate geliefert, die eine Differenzierung der Interglaziale MIS 1, 5, 7 und 9 ermöglichen, bei einem Fehler von 10-15\%.

Die ESR Datierung von Quarz ist eine weitere viel versprechende Datierungstechnik für quartäre und sogar neogene geologische Formationen. Das Vorkommen von Quarz in vulkanischen Gesteinen, Tephren, Störungen und Sedimenten (thermisch beeinflusst und unbeeinflusst) ermöglicht die zeitliche Bestimmung des letzten Zeitpunkts vor der Erhitzung, Störung oder der Aussetzung von Sonnenlicht. Obwohl durch einige experimentelle Ergebnisse angezweifelt, ist die ESR Datierung von Quarz die einzige Möglichkeit Altersdaten älterer Ablagerungen zu liefern.

ESR wurde auch bei einer Vielzahl anderer Materialien angewendet, wie zum Beispiel Foraminiferen, Speleothemen, Travertinen, Kalkkrusten und Zahnschmelz. Die gebräuchlichste und zuverlässigste Anwendung ist die ESR-Datierung von Mammutstoßzähnen. Im Zusammenspiel mit der Laser-Ablation Uranserien Datierung ist ESR eine wichtige Methode zur Altersbestimmung archäologischer Fundstätten jenseits der Bestimmungsgrenzen der Radiokohlenstoffmethode bis in den Bereich von 200 bis $300 \mathrm{ka}$.

Keywords: Electron spin resonance, dating, geochronology, Quaternary, littoral

\section{Introduction}

Although IKeYa (1975) introduced Electron Spin Resonance Spectroscopy (ESR) for dating stalagmites more than 30 years ago, the full potential of this relatively young method is still not fully utilised. Since then, the quality of ESR-spectrometers and the understanding of the structure and behaviour of the ESR signal used for dating have been significantly improved. Detailed overviews about the ESR dating method have been provided by IKEYA (1993), Grün (1989a, 1989b, 2007), RadtKe (1989), Jonas (1997) and Rink (1997).

This method is used for a wide variety of materials with most reliable applications on corals, mollusc shells, quartz, foraminifera, speleothems and teeth. In this text, the potential and present restrictions of ESR dating of Quaternary coral, mollusc shells and quartz is illustrated for selected sites and a short review is presented about the relevance of ESR for dating other carbonates (foraminifera, speleothems) and tooth enamel. For further details about problems and further applications of ESR dating including more literature, see e.g. Grün (2007), Blackwell (2006) and Rink (1997).

Regardless of the recent methodological improvements in ESR and its frequent use for dating corals, mollusc shells, quartz and teeth, there is still a huge potential for further development of the method for these and other materials (e.g. SKINNER 2000). Similar to all other methods of age determination, ESR dating is confronted by specific methodological problems that cannot be considered in error calculation. This means, as applies for most analytic methods, that high precision does not automatically guarantee the accuracy of an age estimate. The latter is influenced by different geological factors that cannot be quantified and are hence not part of the age and error calculation. In ESR dating, these are mainly diagenetic alterations of the dated material, incomplete resetting of the ESR signal and up-take or loss of radioactive elements (U, Th, K) (Fig. 1). With regard to these problems, proving the reliability of new dating approaches by independent age control is essential. In the context of the ESR method, this is possible using radiocarbon or ${ }^{230} \mathrm{Th} /{ }^{234} \mathrm{U}$ dating for corals and mollusc shells or luminescence, palaeomagnetics or ${ }^{40} \mathrm{Ar} /{ }^{39} \mathrm{Ar}$ for dating quartz.

\section{Methodology}

The ESR dating method is one of several radiation exposure methods based on radiation dosimetry such as thermoluminescence (TL), optically stimulated luminescence (OSL) and radioluminescence (RL). All these methods 
use the phenomenon that common minerals act as natural dosimeters. The radiation causes charge (electrons, free radicals) to be trapped at defects in the crystal lattice of a wide range of minerals such as aragonite, calcite and quartz. The amount of trapped charge accumulation increases with time and can be quantified by the ESR measurement.

\subsection{Nature of the ESR signal and its quantification}

The process of trapping charge results from the interaction of naturally occurring alpha, beta and gamma, and, to some minor extent, cosmic radiation ( $\mathrm{D}^{\prime}{ }_{\mathrm{cos}}$, cosmic dose rate) with matter. The first consists of internal radiation from

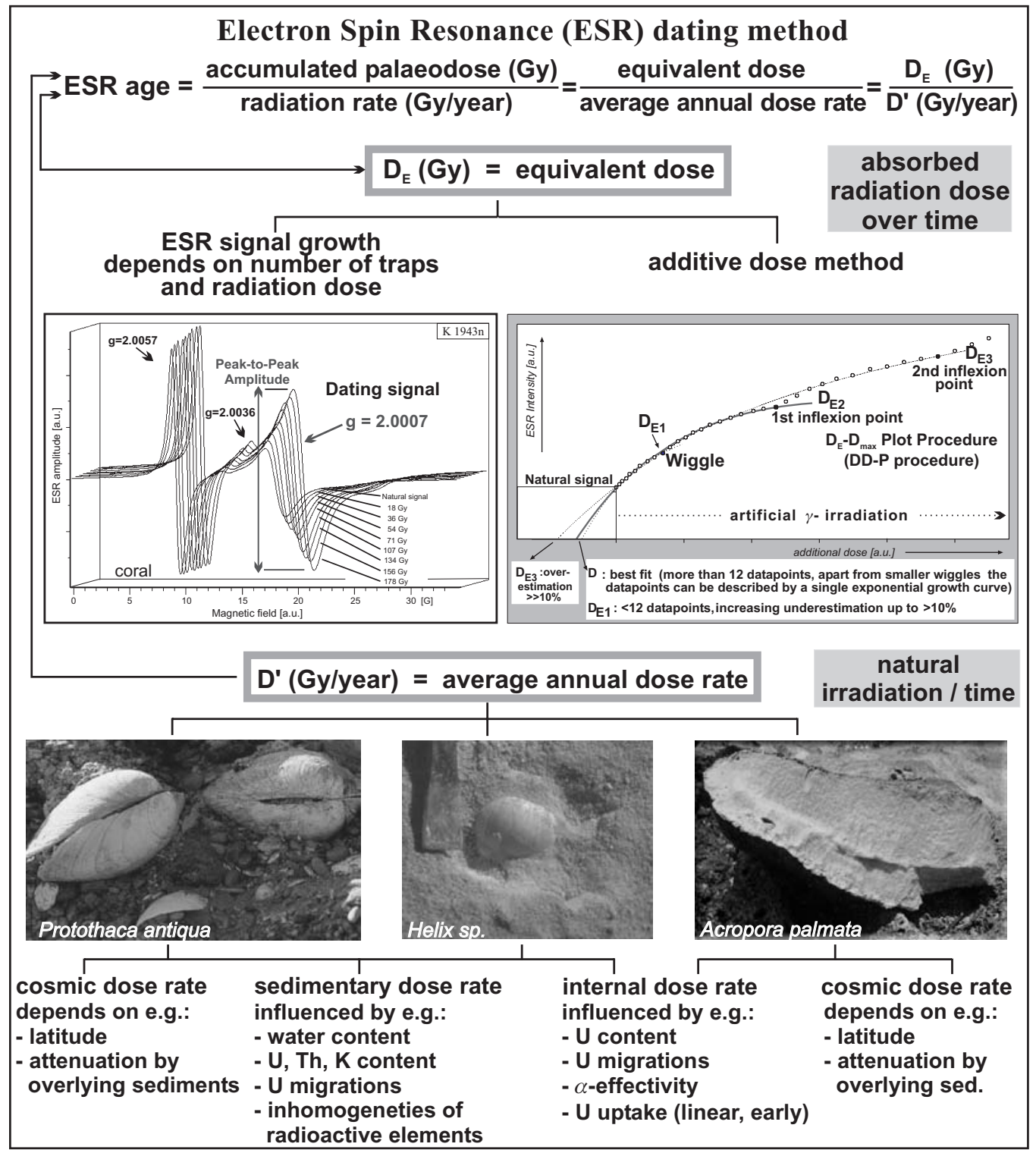

Fig. 1: Generalised principle of ESR dating of aragonitic coral and mollusc shells

Abb. 1: Generalisiertes Schema der ESR-Datierung von Korallen und Muschelschalen. 
the mineral itself $\left(\mathrm{D}^{\prime}{ }_{\text {int. }}\right.$, internal dose rate: i.e. Uranium and daughter isotopes, to some extent additionally $\mathrm{Th}$ and $\mathrm{K}$ in quartz) as well as radiation from the surrounding sediment $\left(\mathrm{D}^{\prime}{ }_{\text {ext. }}\right.$, external dose rate mainly from Uranium and Thorium decay chains and Potassium). Such ionising radiation causes the activation of electrons to an excited energy level. Charge defects in the crystal lattice, so-called traps, capture part of the excited electrons in the band gap. A detailed description of the underlying physical processes is provided by e.g. GRÜN (1989a, 1989b, 2007), Jonas (1997) und Rink (1997). The amplitude of the ESR signal represents the amount of unpaired electrons at lattice defects (traps). Each material investigated has a characteristic ESR spectrum that may consist of one or several single signals, but not all the individual signals are suitable for dating. Suitable are only ESR signals that are both sensitive to radiation and thermally stable at the prevailing temperature that occurred during deposition and burial. The ESR signal at $\mathrm{g}=2.0007$ (Fig. 1 ) is most suitable for dating aragonitic mollusc shells and corals (e.g. RADTKE \& GRÜN 1988, Walther et al. 1992, Schellmann \& RadtKe 1999, 2001). A basic principle in dating biogenic material is that the ESR signal starts to increase after the shell, tooth enamel or coral has been formed.

For ESR dating of quartz, a prerequisite is the existence of a resetting mechanism in nature to zero the ESR signal (and thus the geological clock). In order for the method to be reliable, any pre-existing ESR signals must be erased prior to the event to be dated (Fig. 2). The zeroing process responsible for resetting the geological clock is dependent on the geological context of the quartz mineral. The specific behaviour of ESR centres in quartz allows to determine the moment of the last heating (volcanic rocks, tephra, heated sediments), the moment of the last fault movement (quartz in fault gouges exposed to shearing) and the last exposure to sunlight (sedimentary quartz). The accuracy of the ESR age is dependent on the completeness of the zeroing process. Incomplete signal zeroing will inevitably lead to age

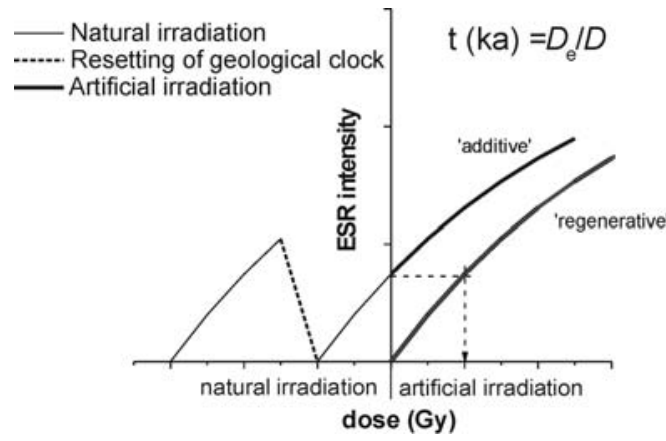

Fig. 2: Generalised principle of ESR dating of quartz. The underlying assumption of ESR dating is that the ESR signal is zeroed prior to the event, which is to be dated (resetting of the geological clock). Subsequently, the ESR signal starts growing again by natural irradiation (left of the intensity axis), until the moment of sampling. In general, there are two methods to infer the accumulated or equivalent dose $D_{E}$. In the additive dose method, artificial doses are given on top of the accumulated dose, and the equivalent dose is estimated by extrapolating the growth-curve back to the x-axis (dose-axis). In the regenerative dose method, the signal is zeroed again, and the natural intensity is projected onto the regenerated dose curve to estimate the equivalent dose.

Abb. 2: Generalisiertes Prinzip der ESR-Datierung von Quarz. Die grundlegende Annahme der ESR-Datierung ist, dass das ESR-Signal vor dem zu datierenden Ereignis auf Null gesetzt wird (Zurückstellen der geologischen Uhr). Danach nimmt das ESR-Signal, aufgrund natürlicher Strahlung, bis zum Zeitpunkt der Probennahme wieder zu (linke Seite der ESR Intensitätsachse). Generell gibt es zwei Methode die Akkumulierte oder Äquivalent Dosis $\left(\mathrm{D}_{\mathrm{E}}\right)$ zu bestimmen. Bei der Additiven Dosis Methode wird auf das natürliche Signal eine künstliche Dosis hinzu gegeben. Die Äquivalent Dosis wird dann durch Abtragen der Wachstumskurve auf der X-Achse bestimmt. Bei der Regenerativen Dosis Methode wird das Signal zuerst auf Null gesetzt und die natürliche Intensität wird auf die regenerative Wachstumskurve projiziert, um die Äquivalent Dosis zu erhalten.

overestimates, unless suitable tests can reliably determine the degree of zeroing that may have occurred, through which this can be accounted for.

Several ESR centres in quartz have shown to be potential dosimeters of ionising radiation 


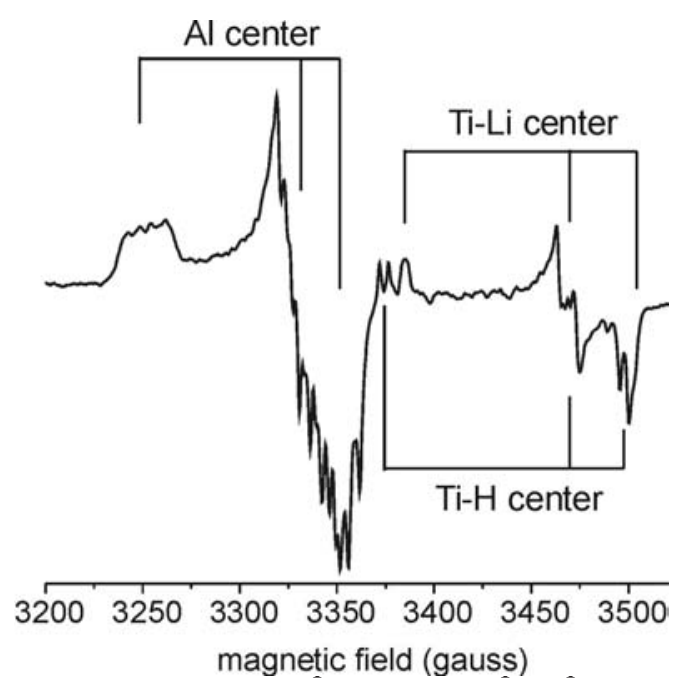

Fig. 3: ESR spectrum of crystalline quartz grains $(100-200 \mu \mathrm{m}, 300 \mathrm{mg})$ at $100 \mathrm{~K}$ (Australian sedimentary quartz). Microwave absorption patterns are indicated for the Al-centre, Ti-Li-centre and Ti-H-centre, according to the 3 principal g-values (vertical lines).

Abb. 3: ESR-Spektrum kristalliner Quarzkörner $(100-200 \mu \mathrm{m}, 300 \mu \mathrm{m})$ bei $100 \mathrm{~K}$ (sedimentärer Quarz; Australien). Mikrowellenabsorptionsmuster sind für die Al-, Ti-Li- und Ti-H-Zentren angegeben, bezogen auf die drei grundlegenden g-Werte (vertikale Linien).

the equivalent of the palaeodose is determined by a so-called additive dose response curve. For this, the sample is irradiated using artificial $\beta$ - or $\gamma$-sources and an individual dose response curve is constructed for each sample. By extrapolation on the $\mathrm{x}$-axis, $\mathrm{D}_{\mathrm{E}}$ is calculated (Fig. 1). The equivalent dose of quartz can also be determined using the regenerative dose method, owing to the regeneration characteristics of the paramagnetic defects in the mineral. Following thermal annealing (heating) or optical bleaching, the ESR signal is regenerated with an artificial radioactive source, and the dose is estimated by interpolation of the natural ESR intensity (Fig. 2).

\subsection{Dose rate determination}

The cosmic dose rate is related to the depth

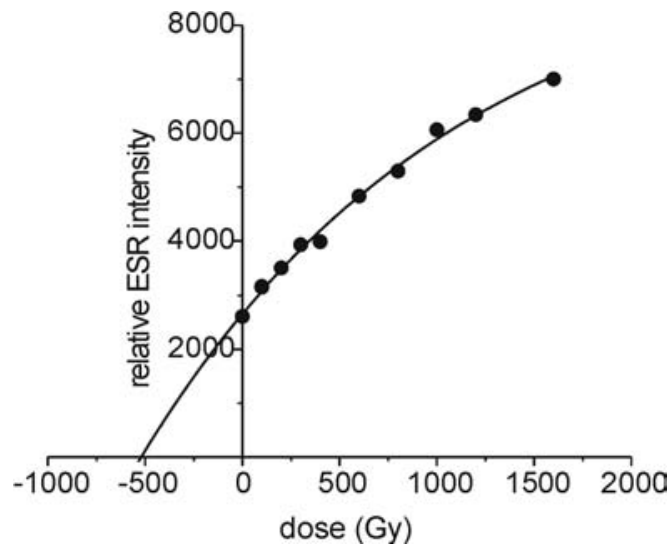

Fig. 4: ESR dose response curve of the Al-centre from an aeolian sample (NWB1, Murray Basin, Australia; unpublished results). The data points are fitted to a rising exponential (GRÜN 1989). Positive values refer to the artificially added doses, while negative values refer to the past irradiation dose. Assuming a dose rate of about $1 \mathrm{~Gy} \mathrm{ka}^{-1}$, which is not uncommon in sedimentary contexts, the dose range covered in this example would equal more than 2 million years.

Abb. 4: ESR-Dosisaufbaukurve für das Al-Zentrum gemessen an einem äolischen Sediment (NWB1, Murray Basin, Australien, unveröffentlichte Daten). Die Datenpunkte sind an einen steigenden Exponenten angepasst (GRÜN 1989). Positive Werte beziehen sich auf die künstlich zugegebene Strahlung, wohingegen negative Werte die in der Vergangenheit akkumulierte Dosis repräsentieren. Unter Annahme einer Dosisleistung von ungefähr $1 \mathrm{~Gy} \mathrm{ka}^{-1}$, was für sedimentäre Ablagerungen nicht ungewöhnlich ist, deckt die akkumulierte Dosis in diesem Beispiel eine Spanne von mehr als 2 Millionen Jahren ab.

of the sample below surface, latitude and elevation. Further corrections to burial depth may be needed where nearby obstructions or drop-offs in the land surface occur: these are not accounted for by the tables of PRESCOTT \& Hutton (1994). The radioactivity of the surrounding material is either measured in the field using a portable gamma spectrometer or calculated via the determination of the concentration of Potassium, Thorium and 


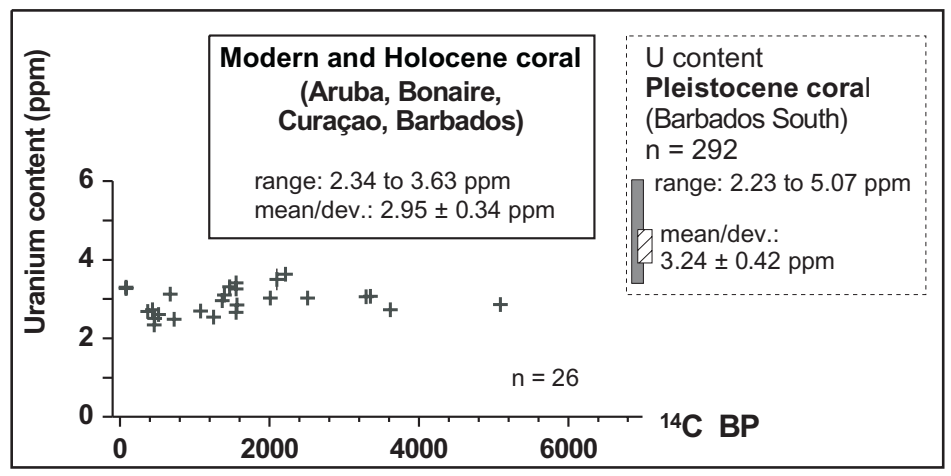

Fig. 5: Uranium content (ppm) of modern, Holocene and Pleistocene corals (slightly modified from SCHELLMANN \& RADTKE 2003).

Abb. 5: Uran-Gehalte (ppm) moderner, holozäner und pleistozäner Korallen (leicht verändert nach SCHELLMANN \& RADTKE 2003).

Uranium in the sample. For aragonitic mollusc shells and corals, the internal dose rate is caused almost completely by Uranium. If possible, the Uranium content of each sample should be verified by repeated measurements. In contrast, the internal alpha dose rate in quartz is usually very small in comparison with the external dose rate, allowing it to be neglected in the final age calculation. Most sub-modern, Holocene and Pleistocene corals have Uranium contents of about 3.0 to 3.2 ppm (Fig. 5). It is hence concluded that corals absorb such amounts of Uranium from seawater during their life-time or shortly after their death. Extremely high (up to 5 ppm) and low (below $2.5 \mathrm{ppm}$ ) Uranium concentrations are exceptional and at the moment, it can only be speculated about their origin.

For the calculation of ESR ages of corals, an early Uranium up-take and hence a relatively high radiation level from the very beginning can be assumed. This is of importance as ESR ages that are calculated based on an early Uranium up-take model will result in much lower age estimates compared to ages calculated based on the assumption of a linear Uranium uptake. In contrast to this, modern mollusc shells have extremely low Uranium contents of 0.1 to $0.2 \mathrm{ppm}$ (max. $0.7 \mathrm{ppm}$ ). Only after an age of more than $2500 \mathrm{yr}$, do mollusc shells show significantly higher contents of more than 2 ppm Uranium (Fig. 6) and reach levels frequently observed in Pleistocene fossils. This implies that mollusc shells absorb most of the Uranium post mortem. However, this delayed up-take of Uranium is negligible for age calcu- lation when dating Pleistocene mollusc shells. For Early to Mid Holocene mollusc shells, which have Uranium contents higher than 0.5 ppm, a delayed up-take of Uranium has to be considered when calculating the internal dose rate. As the exact post-mortem up-take of Uranium cannot be reconstructed, the true age will be between the ESR ages estimates calcu-

Table 1: Exemplarily calculation of the effect of different Uranium contents on the ESR age of a Holocene mollusc shell at constant external dose rate. Shown are the age differences that result from linear Uranium up-take and early Uranium up-take, respectively.

Tab. 1: Exemplarische Berechnung zur Verdeutlichung des Einflusses unterschiedlicher Uran-Gehalte auf die ESR-Alter holozäner Muschelschalen unter der Annahme einer konstanten externen Dosisleistung. Sichtbar werden die Altersunterschiede, die aus einer linearen bzw. einer früheren Uranaufnahme resultieren.

\begin{tabular}{cc}
\hline $\begin{array}{c}\text { U content } \\
(\mathrm{ppm})\end{array}$ & $\begin{array}{c}\text { linear U-uptake model } \\
\text { (ESR age diff. to early } \\
\text { U-uptake model) }\end{array}$ \\
\hline$<0.6$ & same age \\
0.7 & $+140 \mathrm{yrs}$. \\
1.0 & $+200 \mathrm{yrs}$. \\
1.5 & $+270 \mathrm{yrs}$. \\
2.0 & $+350 \mathrm{yrs}$. \\
2.5 & $+400 \mathrm{yrs}$. \\
3.0 & $+460 \mathrm{yrs}$. \\
3.5 & $+510 \mathrm{yrs}$. \\
4.0 & $+560 \mathrm{yrs}$. \\
4.5 & $+600 \mathrm{yrs}$. \\
5.0 & $+640 \mathrm{yrs}$. \\
\hline
\end{tabular}


lated for linear and early Uranium up-take. For Late Holocene mollusc shells with Uranium contents $>0.5 \mathrm{ppm}$, linear up-take represents probably the most likely scenario. A detailed discussion of Uranium up-take is provided by JonAS (1997) and RinK (1997). Depending on the contribution of internal dose (= Uranium content of mollusc shell) to the total dose rate, differences in age between the two models will be up to $1000 \mathrm{yr}$ (and more) for samples having a high Uranium content ( $>5 \mathrm{ppm}$ ). For Uranium contents below $0.6 \mathrm{ppm}$, both models usually result in age estimates consistent within error. Table 1 demonstrates the effect of Uranium up-take on the ESR age of a mid-Holocene mollusc shell.

There are several other potential sources of error associated with dose rate determination that may lead to incorrect ESR ages (Fig. 1). Among these is a change in past sediment water content that can hardly be quantified and may have caused variations in external dose rate. However, this can be accommodated by placing a very large error on the water content in the calculations, for example a value of up to $100 \%$ of the water content. Another potential problem can be radioactive disequilibria, i.e. the loss or gain of radioactive elements mainly from the Uranium decay chain (e.g. loss of soluble Uranium). Furthermore, calculation of dose rate for mollusc shells from heterogenous settings, i.e. poorly sorted sand and gravel, is much more insecure than for samples (e.g. land snail shells) from homogenous environments such as aeolianites. Only a few problems are associated with the dose rate determination of

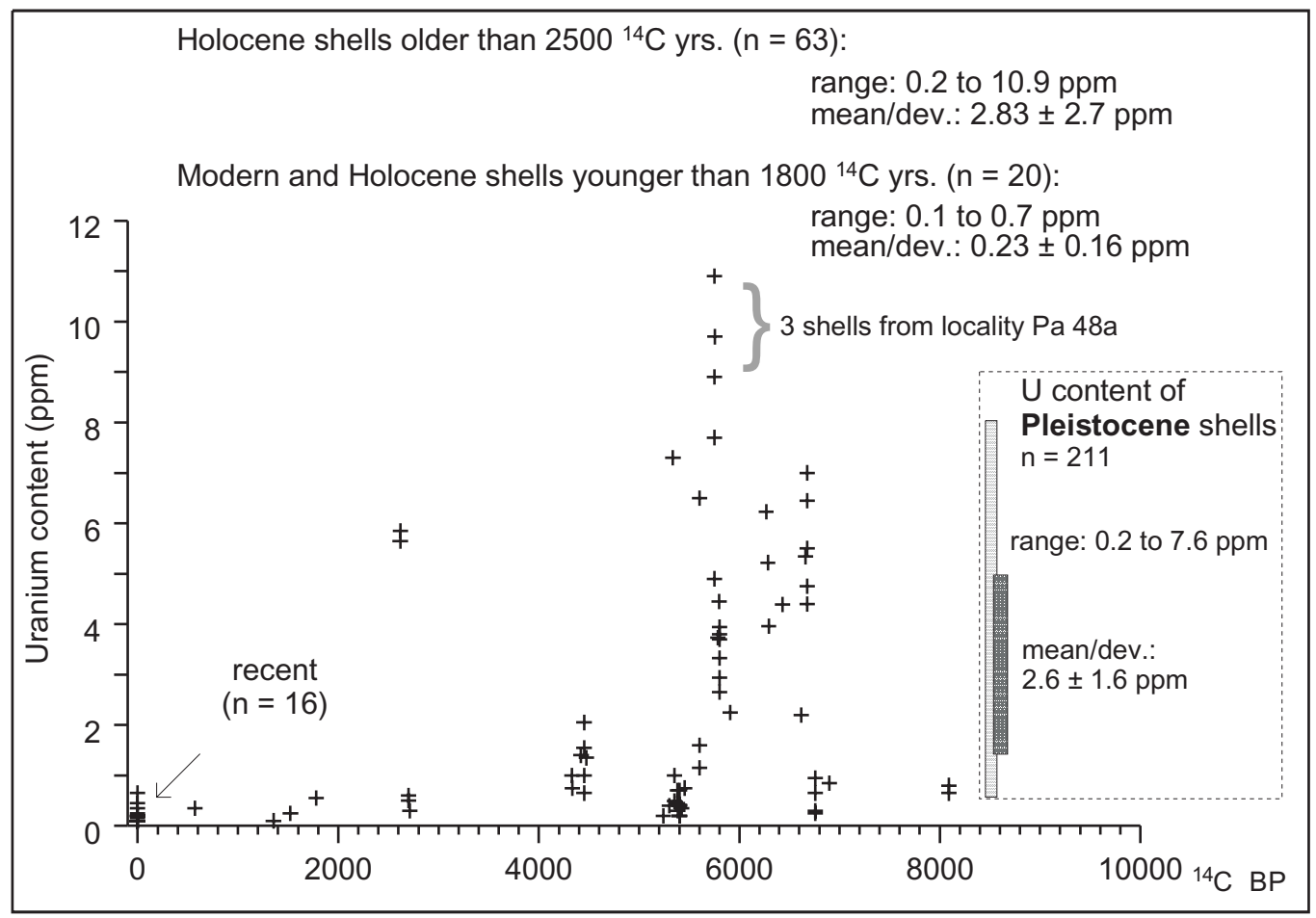

Fig. 6: Uranium content ( $\mathrm{ppm}$ ) of modern, Holocene and Pleistocene mollusc shells from Schellmann \& RADTKE (2007). In addition to the Uranium content of radiocarbon dated mollusc shells, values measured for in situ bivalve shells that were collected from the same horizons are included.

Abb. 6: Uran-Gehalte ( $\mathrm{ppm})$ moderner, holozäner und pleistozäner Muschelschalen (aus ScheLLMANN \& RADTKE 2007). Zusätzlich zu den Uran-Gehalten der ${ }^{14} \mathrm{C}$-datierten Muschelschalen, sind auch die Werte von den in situ im gleichen Horizont gefundenen bivalven Schalen angegeben. 
corals since only cosmic radiation and internal Uranium are relevant for total dose rate (Fig. 1 ). The problems of changing water content in the surroundings of the sample and erosive or accumulative processes that may affect cosmic dose calculation have only minor effects.

Supplementary uncertainties in the dose rate for ESR dating of quartz are due to variations in water content and disequilibria in the decay chains of $U$ and $T h$. Radioactive disequilibrium (i.e. a misbalance between parent and daughter nuclides) might occur if one (or more) of the Th- and/or U-chain members are lost or gained during burial, an effect that would be more pronounced in very permeable sediments. Especially, radionuclides of $\mathrm{Rn}$ (gas) and $\mathrm{Ra}$ (very leachable), which occur halfway in the $\mathrm{U}$ - and Th-chains, could induce disequilibrium. In the case of sediments, it is also possible that disequilibrium already existed at the time of deposition. In order to calculate an accurate dose rate, it is important to check whether any equilibrium exists and if so, whether this equilibrium has remained constant over time. However, in many dating studies, radioactive equilibrium is simply assumed.

A further error source in the calculation of ESR ages is the only poorly known so-called alpha-efficiency, which is also known as $\mathrm{k}$-factor (see JonAs 1997 for details). This value describes the efficiency of $\alpha$-particles to induce ESR signals compared to other kinds of radiation. GRÜN (1985) and GRÜN \& KATZENBERGER (1994) experimentally determined by using a ${ }^{241} \mathrm{Am} \alpha$-source k-values between 0.07 and 0.10 for mollusc shells. For corals, RADTKE \& GRÜN (1988), GRÜN et al. (1992) and Malmberg \& RadtKe (2000) determined $\mathrm{k}$-values between 0.05 and 0.07 . According to LyONS (1987, cit. in RADTKE \& GRÜN 1988) the actual alpha-efficiency of particles from the Uranium decay chain is $20-30 \%$ higher then the values determined using a monoenergetic artificial $\alpha$-source. Following GRÜN (2007: 1509), the best $\mathrm{k}$-values for molluscs are $0.07 \pm 0.01$, for corals $0.06 \pm 0.02$ and for tooth enamel $0.13 \pm 0.02$. The influence of uncertainties on the $\alpha$-efficiency in quartz is re- duced because the internal alpha dose rate can usually be neglected (cf. supra). Furthermore, the influence of external alpha rays (several $10 \mu \mathrm{m})$ is erased by sample preparation techniques using HF-solutions. As such, in many cases the total dose rate to quartz can be simplified to the sum of the external beta and gamma dose rate and the cosmic dose rate.

\section{ESR dating of aragonitic coral and marine and terrestrial mollusc shells}

Besides the problems in dose rate determination mentioned above, ESR dating of mollusc shells and corals is associated with another uncertainty that has yet not been quantified. This problem is related to the amplitude of the ESR signal of most mollusc shells, and also rarely for corals, which does not show simple exponential growth to saturation resulting from artificial gamma irradiation. Instead, so-called inflexion points (Fig. 1) have been observed at which signal growth increases suddenly. The physical nature of these inflexion points is yet only poorly understood. Most likely, it results from interference of the ESR dating signal with the so-called a-complex, which shows a relatively higher increase at higher doses and apparently individually disturbs the signal used for dating (KATZENBERGER \& Willems 1988, BARABAs et al. 1992). However, it is also possible that inflexion points are related to defects in the crystal lattice that are produced by gamma irradiation (GRÜN 1990). Attempts to eliminate inflexion points without alternating the ESR dating signal by changing the parameters of the ESR measurement or including thermal pre-treatments have not been successful so far (e.g. BRumby \& Yoshida 1994a, HoFfmanN et al. 2001, Molodkov et al. 1998). Different preheat temperatures and durations can actually cause significant differences in $D_{E}$ values and consequently different ESR ages (SCHELLMANN \& RADTKE 2007). Discontinuous growth of the ESR signal can cause overestimation of calculated $\mathrm{D}_{\mathrm{E}}$ of more than $10 \%$ when too high artificial doses are used for construction of the dose response curve (Fig. 1). For determination 
of $\mathrm{D}_{\mathrm{E}}$ values, only the undisturbed, low-dose part of a dose response curve prior to reaching the first inflexion should be used. Only this part is dominated by the growth of the ESR dating signal and should reflect natural increase. This part of the growth curve can be described by a simple exponential saturation curve. The impact of inflexion points can be minimised by either using several dose points in the lower part of the dose response curve or by applying the standardised procedure of $\mathrm{D}_{\mathrm{E}}-\mathrm{D}_{\text {max }}$-plots (DDP) (Fig. 1; Schellmann \& RadtKe 1999, 2001, 2003). Nevertheless, inflexion points are probably the main reason for age scatter observed in isochronal samples within mollusc bearing sediment layers. Additive dose response curves of corals, on the other hand, rarely show pronounced inflexion points, presumably the reason why ESR dating of isochronal corals scatter much less than molluscs (see below). The $D_{E}$ values of all ESR ages mentioned here were determined using $\mathrm{D}_{\mathrm{E}}-\mathrm{D}_{\max }$ plots. Prior to this, mollusc and coral samples were ground by hand and sieved to $125-250 \mu \mathrm{m}$. At least 20 aliquots with a weight of $0.2000 \mathrm{~g}$ were prepared and irradiated using a ${ }^{60} \mathrm{Co}$-source (Centre of Nuclear Medicine, University of

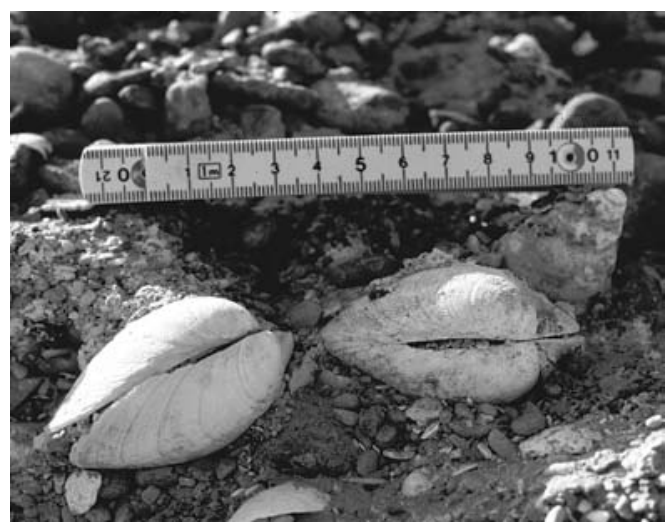

Photo 1: Articulated mollusc shell (Protothaca antiqua) in Last Interglacial $\mathrm{T}_{[5]}$ beach deposits near Bustamante, Patagonian Atlantic coast.

Foto 1: Muschelschalen von Protothaca antiqua in Lebendstellung in Strandablagerungen des letzen Interglazials $\mathrm{T} 3_{[5]}$ an der patagonischen Atlantikküste nahe Bustamante.
Düsseldorf); dose rate between 0.8 and $2.5 \mathrm{~Gy}$ $\mathrm{min}^{-1}$ ). The maximum irradiation dose was typically between two and three times $\mathrm{D}_{\mathrm{E}}$. Typical parameters on the ESR spectrometer were 10 or $25 \mathrm{~mW}$ microwave power, 0.5 or $1.0-1.2 \mathrm{G}$ modulation amplitude, $41.9 \mathrm{~s}$ scan-time, 40-50 $\mathrm{G}$ scan width and 5 to 40 scans. All $\mathrm{D}_{\mathrm{E}}$ values were determined using the programme „Fitsim“ (version 1993) and ESR ages were calculated using the programmes „Data IV“ (version 1990) and „Data V.6“ (version 1999), written by Rainer Grün.

\subsection{Comparing ESR, TIMS Th/U and radiocarbon dating results ages of mollusc shells from Holocene as well as Late and Middle Pleistocene littoral terraces of the Patagonian Atlantic coast}

Since several early systematic studies (RADTKE et al. 1981, IKeya \& OMUhra 1981), dating of molluscs is one of the most common applications of ESR dating and has been applied in several regions worldwide. Particularly typical for the example presented here, the Atlantic coast of Patagonia, is the phenomenon that the coarse littoral beach deposits frequently bear articulated mollusc shells (Photo 1). Such objects are very sensitive to movement and clearly indicate their in situ nature. This could be proven by radiocarbon dating of several bivalve mollusc shells found in one sediment layer (Schellmann 1998, Schellmann \& RADTKE 2007). The dating of several in situ and isochronous mollusc shells (deposited within not more than a few decades) represents an ideal opportunity to test the accuracy of the ESR dating method. With this approach, it is possible to test the reproducibility of ESR dating with special regard to the dating of Pleistocene molluscs, where no other accurate dating methods are available.

Along the Patagonian Atlantic coast, there are several locations where Holocene and Pleistocene littoral deposits with articulated mollusc shells can be found at different elevations. The distribution of raised Pleistocene beach deposits in the Bay of Bustamante is shown in 


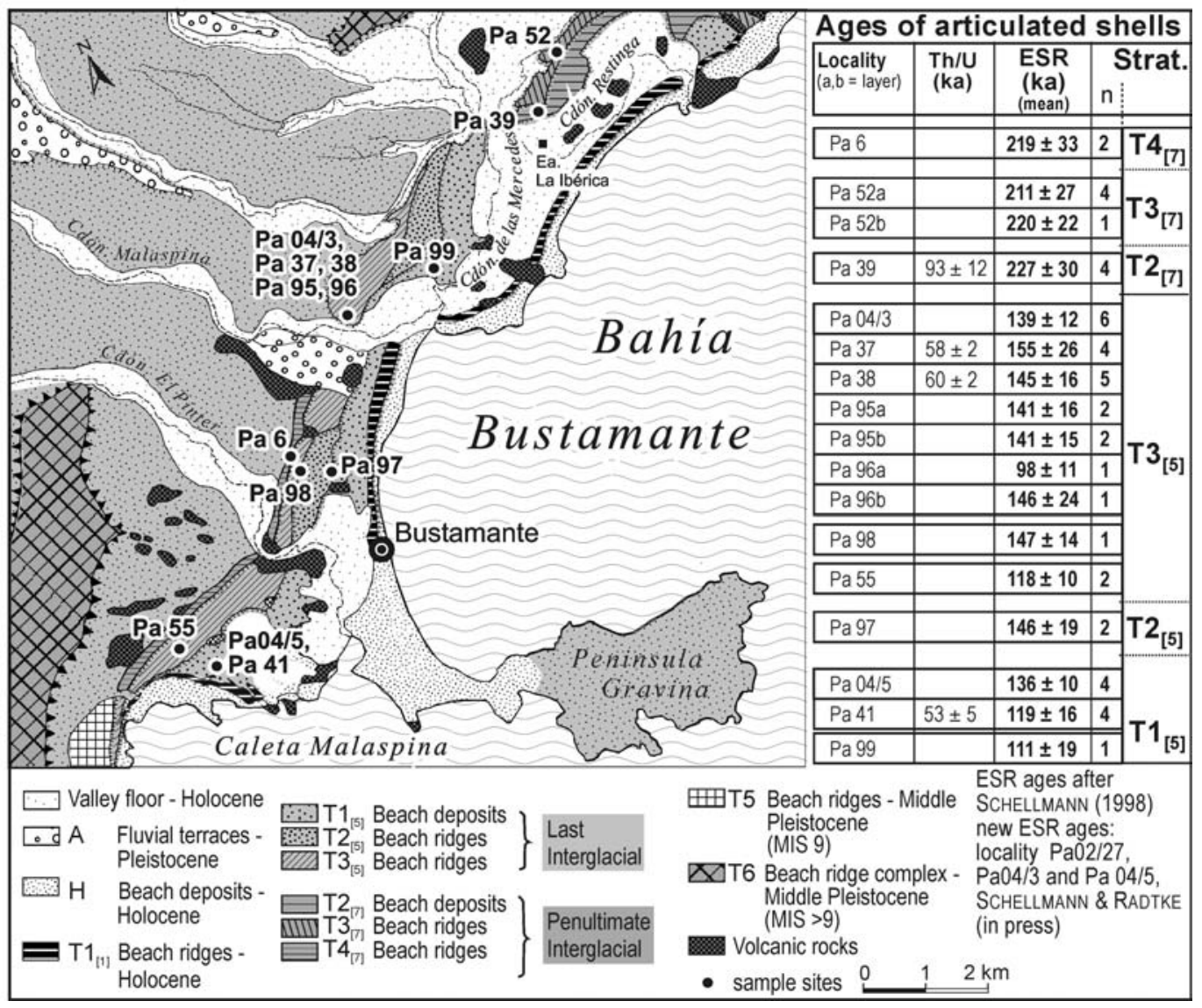

Fig. 7: ESR (mean ages) and TIMS Th/U ages of articulated mollusc shells of Last and Penultimate Interglacial beach ridge systems along the Patagonian Atlantic coast near Bustamante. TIMS Th/U dating by A. Rostami \& A. Mangini (Institut für Umweltphysik, Universität Heidelberg); details in Schellmann (1998) and Schellmann \& RadtKe (2000).

Abb. 7: ESR (gemittelte Alter) und TIMS Th/U Alter gemessen an Muschelschalen in Lebendstellung aus Strandwallsedimenten des letzen und vorletzen Interglazials entlang der patagonischen Atlantikküste in der Nähe von Bustamante. TIMS Th/U Datierungen wurden von A. Rostami \& A. Mangini am Institut für Umweltphysik, Universität Heidelberg durchgeführt. Details bei Schellmann (1998) und Schellmann \& RAdTKE (2000).

Fig. 7 together with the results of TIMS Th/U and ESR dating, mainly of bivalve molluscs found in the sediments (SCHELLMANN 1998). ESR dating confirms the general morphological and pedostratigraphic differences between the individual beach ridge systems of the area (Schellmann 1998). Beach ridges in distal position to the present shoreline ( $\mathrm{T} 4_{[7]}$ to $\left.\mathrm{T} 2_{[7]}\right)$ developed during the Penultimate Interglacial (ca. 220,000 yr ago). The beach ridge systems closer to the sea, $\mathrm{T}_{[5]}$ to $\mathrm{T} 1_{[5]}$ were formed during the Last Interglacial (ca. 130,000 yr ago). The ESR ages are not precise enough to allow a differentiation in age between different beach ridge systems such as $\mathrm{T} 4_{[7]}$ to $\mathrm{T} 2_{[7]}$ and $\mathrm{T} 3_{[5]}$ to $\mathrm{T}_{[5]}$, respectively. Additionally, both Holocene (Fig. 9) and Last Interglacial ESR ages apparently tend to overestimate the real age of the sample. The results of TIMS Th/U however, appear much too young and do not allow a 


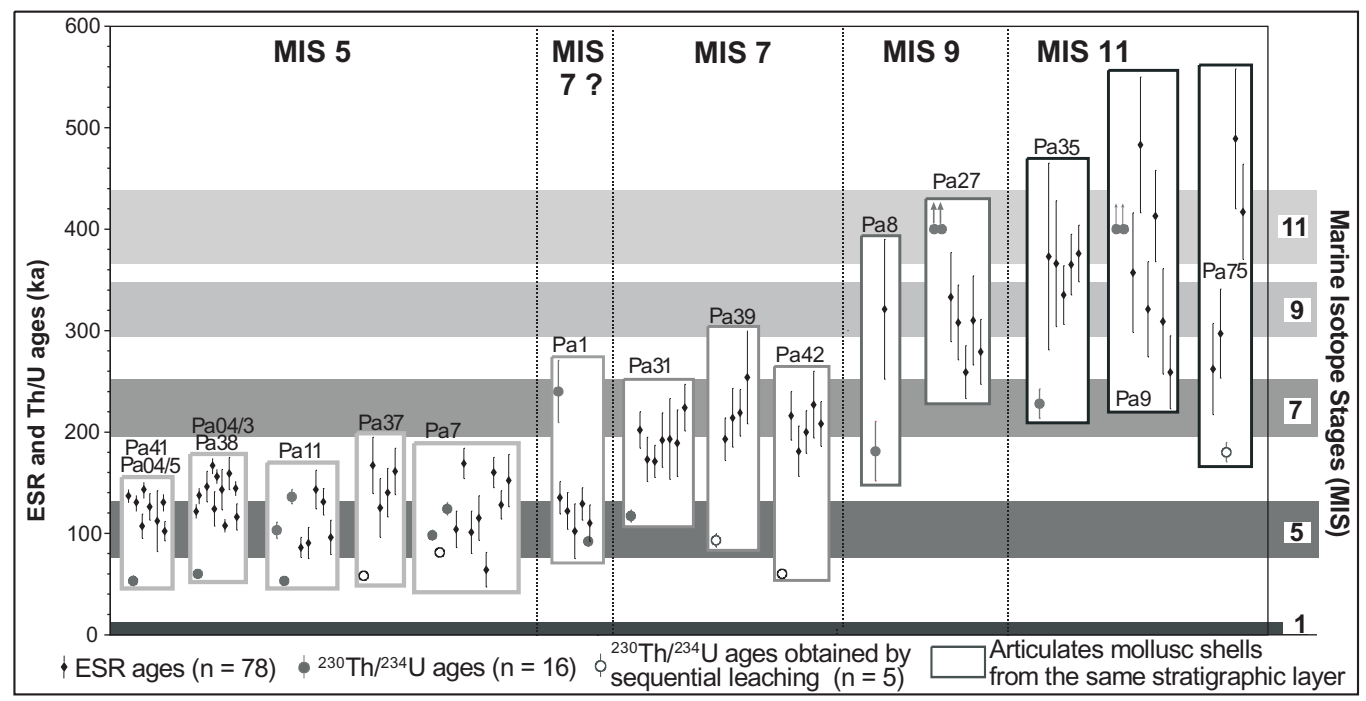

Fig. 8: Comparison of ESR and TIMS Th/U ages of mollusc shells from Late and Middle Pleistocene beach ridge systems along the Patagonian Atlantic Coast. TIMS Th/U dating by A. Rostami \& A. Mangini (Institut für Umweltphysik, Universität Heidelberg); details in Schellmann (1998) with additional datings from Schellmann \& RADTKe (2007).

Abb. 8: Vergleich der ESR- und TIMS Th/U Alter von Muschelschalen aus spät- und mittelpleistozänen Strandwallsystemen entlang der patagonischen Atlantikküste. TIMS Th/U Datierungen wurden von A. Rostami \& A. Mangini am Institut für Umweltphysik, Universität Heidelberg durchgeführt; Details bei ScHELLMANN (1998) mit zusätzlichen Daten aus SchelLmanN \& RADTKE (2007).

differentiation between beach ridge systems of the Last and Penultimate Interglacial (Fig. 7). A similar picture is also revealed when comparing the whole data set of ESR and Th/U dating from different localities along the Patagonian Atlantic coast (Fig. 8). Only the ESR ages allow, with an error of 10-15\%, a geochronological differentiation between Last and Penultimate Interglacial littoral terraces. In cases were several datings are available, a differentiation of beach deposits belonging to Marine Isotope Stage (MIS) 9 is partly possible.

For Holocene mollusc shells, radiocarbon dating can be an independent reliability control for ESR dating. Although such a comparison shows fairly good agreement and reproducibility, it is obvious that significant discrepancies do occur (Fig. 9). It should be kept in mind that articulated mollusc shells within a sediment layer certainly are of the same age. As the external dose rate within the sediment is equal for all samples and possible variations of internal dose rate cannot account for the observed age differences, the variation in age must be related to $D_{E}$ calculation and some not yet known properties of the ESR dating signal at $\mathrm{g}=2.0007$. We can conclude that ESR ages of Holocene and Pleistocene mollusc shells can scatter substantially and result in significantly too high age estimates. It is hence necessary to date several shells out of a sediment layer to establish a reliable chronological frame for marine terraces. The given accuracy of ESR dating of mollusc shells will, however, only allow correlating the littoral deposits with certain interglacials but not more precisely.

\subsection{ESR dating of Late Pleistocene land snail Helix sp. from aeolianites of the $\mathrm{SE}$ coast of Cyprus}

Although first ESR dates for mollusc shells 


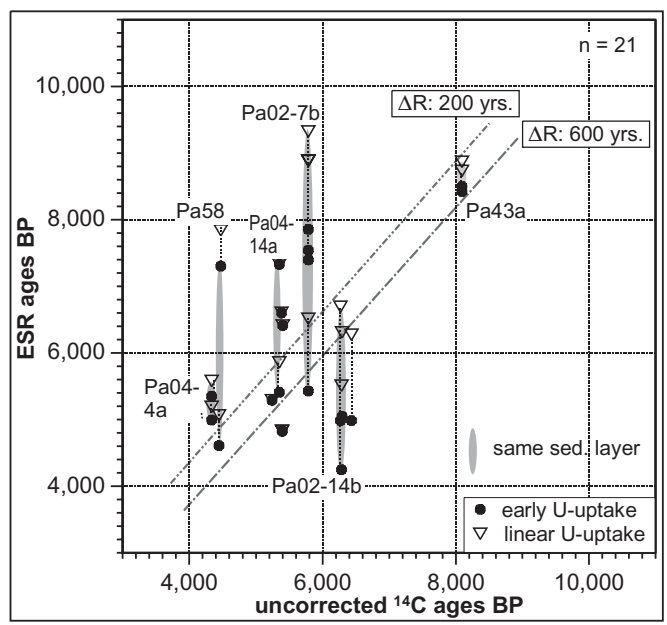

Fig. 9: Comparison of Radiocarbon and ESR ages on articulated Holocene mollusc shells from the Patagonian Atlantic coast (details in SchelLmann \& RADTKE 2007).

Abb. 9: Vergleich von ${ }^{14} \mathrm{C}$ - und ESR-datierten, artikulierten Muschelschalen aus dem Holozän an der patagonischen Atlantikküste (Details bei ScHelLMANN \& RADTKE 2007).

have been produced by RADTKE (1985), little research has been carried out on dating land snails (e.g. Molodkov 1993, SkinNer \& Shawl 1994, Engin et al. 2006). A comprehensive study on this topic was conducted by SCHELLMANN \& KeLletAT (2001) on snail shells gathered from aeolianites from the SE coast of Cyprus. The Late Pleistocene aeolianites are spread over several kilometres along the coast and are exposed in cliffs caused by littoral erosion. In some areas, such as along the coast at Nissi Beach (Fig. 10), the basal part of the aeolianite is visible just below present sea level. As the southern coast of Cyprus has only been weakly uplifted since the Last Interglacial (Schellmann \& Kelletat 2001), the deposition of the aeolianite probably occurred during times when the sea level was near the coast and therefore only a few ten metres below its present position. During the Late Pleistocene, such sea level stands occurred during the later parts of MIS 5.

Snail shells of Helix sp. have been used to confirm this geomorphologic interpretation of the age of the aeolianites by means of geochronology (Fig. 10). According to ESR dating, the deposition of dune sands at Cape Greco took place between ca. 66,000 to 72,000 years ago. At Nissi Beach, snail shells from the aeolianites have been dated to ca. 84,000 to 95,000 yr. According to this data, deposition of the youngest aeolianites took place during the second half of MIS 5 when the sea level was not deeper than some ten metres below the present position (e.g. THOMPson \& Goldstein 2005; Radtke \& Schellmann 2005: 99ff.). Radiocarbon dating of the mollusc shell gave much lower ages (Fig. 10) and cannot be used for geochronological interpretations. This confirms the well-known phenomenon that the upper dating limit of radiocarbon dating of carbonates is often reached at about 25,000 to 30,000 yr (RADTKE 1988). The reliability of ESR dating is impressively confirmed at Cape Greco, where the aeolianites are situated on top of beach deposits of the transgression phase of the Last Interglacial (Fig. 8). ESR dates of single shells from these marine deposits indicate an age of 130,000 to 137,000 yr. All together, the results from Cyprus underline the potential of ESR to date terrestrial molluse shells.

\subsection{ESR dating of Pleistocene corals from Barbados}

Due to the fact that dose rate determination is relatively unproblematic, as already discussed above, the dating of aragonitic corals has a rather high potential. First test studies on ESR dating of corals were published in the late 1980s (IKeYA \& OMUhra 1983, RADTKE \& GRÜN 1988, RADTKE et al. 1988, RADTKE 1989, GRÜN et al. 1992) and since then, several methodological improvements and the development of more stabile and high-resolution ESR spectrometers have significantly increased the quality of the dating results. It is now not only possible to distinguish between the major periods of high sea level during the last 500,000 yrs but also to differentiate between sub-maxima, for example, during MIS 5 (e.g. SchellmanN 


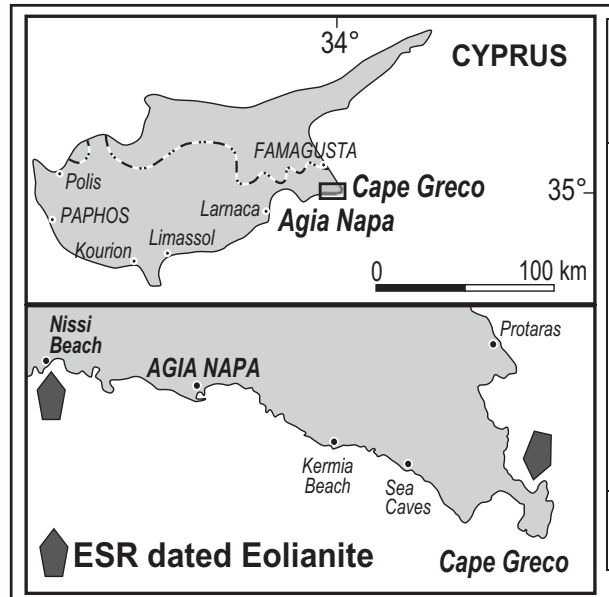

\begin{tabular}{|c|c|c|c|c|c|c|}
\hline \multirow[t]{2}{*}{ Locality } & \multirow{2}{*}{$\begin{array}{l}\text { Lab. } \\
\text { No. }\end{array}$} & \multirow{2}{*}{$\begin{array}{c}\text { Elevation } \\
\text { (m asl.) }\end{array}$} & \multicolumn{2}{|c|}{$\begin{array}{c}\text { ESR ages } \\
\text { early U. }\end{array}$} & \multicolumn{2}{|c|}{${ }^{14} \mathrm{C}$ age } \\
\hline & & & (ka) & \pm & (a BP) & $\delta^{13} \boldsymbol{C}$ \\
\hline \multirow{8}{*}{$\begin{array}{c}\text { Cape Greco } \\
\text { (P1/98, } \\
\text { P1/00) }\end{array}$} & K 2867 & 14.5 & 72 & 5 & \multirow{2}{*}{$\begin{array}{c}32,500 \pm \\
1800\end{array}$} & \multirow{2}{*}{-8.3} \\
\hline & K 4053 & 14.5 & 67 & 6 & & \\
\hline & K 2866 & 11.5 & 88 & 10 & \multirow{2}{*}{$\begin{array}{c}35,000 \pm \\
900\end{array}$} & \multirow{2}{*}{-6.18} \\
\hline & K4052 & 11.5 & 66 & 4 & & \\
\hline & K 2865 & 11 & & & \multirow{2}{*}{$\begin{array}{c}29,800 \pm \\
1000\end{array}$} & \multirow{2}{*}{-7.51} \\
\hline & K 4051 & 11 & 70 & 7 & & \\
\hline & K 4050 & 11 & 71 & 6 & \multirow[b]{2}{*}{$6,376 \pm 79$} & \multirow{2}{*}{-8.56} \\
\hline & K 2808 & 12 & ca. 6.8 & & & \\
\hline \multirow{2}{*}{ Nissi Beach } & K 4054 & $\leq 12$ & 84 & 6 & & \\
\hline & K 4055 & $\leq 12$ & 95 & 7 & & \\
\hline
\end{tabular}

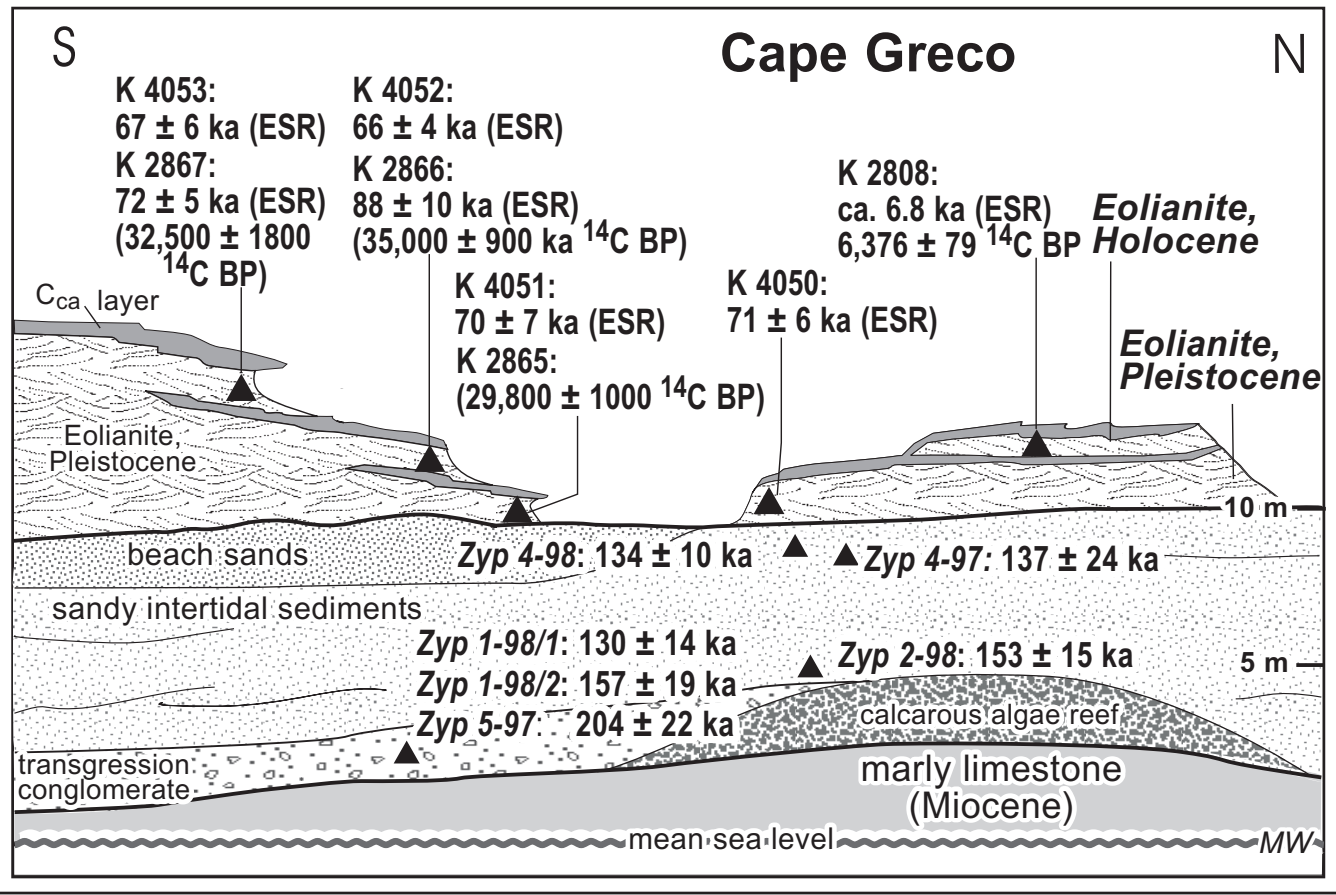

Fig. 10: Radiocarbon and ESR ages of Late Pleistocene aeolianites and beach deposits from the SE coast of Cyprus (Schellmann \& Kelletat 2001).

Abb. 10: ${ }^{14} \mathrm{C}$ - und ESR-Alter spät-pleistozäner äolischer Ablagerungen und Strndablagerungen von der Südost-Küste Zyperns (Schellmann \& KelLetat 2001).

et al. 2004a; Schellmann \& RAdtKe 2004a). Prerequisite is that numerous corals from one stratigraphic unit and ideally from several locations are dated. Only with this approach, can the effect of weak diagenetic alterations of the coral material and the resulting underestima- tion of ESR ages be detected from the scatter of individual results. The high quality of ESR dating is proven by comparison with TIMS U/Th dating. For this purpose, up-lifted Late Pleistocene corals from different elevations and age from the southern coast of Barbados 
were systematically investigated (Fig. 11). At an elevation of 21 to $43 \mathrm{~m}$ above present sea level (asl.), three different coral reefs that formed during the transgression maximum of MIS 5e were identified. Three coral reefs at an elevation between 4 and $17 \mathrm{~m}$ asl. are correlated with the sub-maximum of MIS 5c and two further reef terraces at 2-3 $\mathrm{m}$ asl. are interpreted to represent sub-stages MIS $5 \mathrm{a}_{1}$ and MIS 5a $\mathrm{a}_{2}$ (Schellmann \& RadtKe 2004a, Schellmann \& RadtKe 2004b).

The relatively large scatter of ESR ages determined for individual coral reef terraces is most likely caused by weak diagenetic alterations, which cause re-crystallisation and/or up-take of Uranium. The result is that some ESR ages underestimate the real age of the sample. As a consequence, the oldest ESR samples are more likely to represent the actual age of a coral reef and should hence be used for the chronological interpretation. When more than 20 ESR ages were available for a coral reef terrace, this was accounted for by using the 90 percentile value, and if less than 20 ages were available, then the upper quartile value was used to determine the mean age of the reef. Comparing the results of this approach with the median of U/Th dating shows a rather good concordance (Table 2). Differences in age are on average not more than $3000 \mathrm{yr}$ and hence within the error of ESR dating.

Generally, TIMS U/Th of Late Pleistocene corals is considered to be a highly precise method with analytical errors of $<1 \%$. However, comparing the results of ESR and TIMS Th/U dating of Last Interglacial corals from Inch Marlowe Point (Fig. 12) and Batts Rock Bay (Fig. 13) reveals that the quality of TIMS U/Th is not better than that of ESR (SCHELLMANN et al. 2004a). At Inch Marlowe Point, ESR ages are about 1000 to $8000 \mathrm{yr}$ younger than TIMS U/Th regardless the actual age of the samples. The upper quartile value of all ESR ages is $73,100 \mathrm{yr}$ and the median of all U/Th ages is $76,700 \mathrm{yr}$. Interestingly, the spread of individual ages (not considering error) for both methods is about $4000 \mathrm{yr}$, although all ages were produced on individuals from the same branch of corals and are hence most likely of the same age (grown within not more than a few hundred years). Hence, the high precision of the TIMS U/Th measurements $(\sim 1 \%)$ apparently does not completely account for the observed scatter in ages of isochronal samples. In contrast, the observed scatter of ESR dating is explained by the relatively high analytical error (low precision) (5-8 \%). Hence, when considering the whole data set, the accuracy of

Table 2: ESR ages (upper quartile values) and TIMS U/Th ages (median values) from coral samples from the south and west coast of Barbados. TIMS U/Th dating by E.-K. Potter (Australian National University, Canberra); Details are provided by SchelLMANn et al. (2004a).

Tab. 2: ESR Alter (Werte oberes Quartil) und TIMS U/Th Alter (gemittelte Werte) von Korallenproben der Süd- und Westküste von Barbados. Die TIMS U/Th-Datierungen wurden von E.-K. Potter (Australian National University, Canberra) durchgeführt. Für weitere Details siehe Schellmann et al. (2004a).

\begin{tabular}{cccccccc}
\hline Strat. & Terrace & \multicolumn{3}{c}{ ESR ages } & \multicolumn{3}{c}{ U/Th ages } \\
& & ka & \pm & $\mathrm{n}$ & $\mathrm{ka}$ & \pm & $\mathrm{n}$ \\
\hline MIS 5a-1 & $\mathrm{T} 1 \mathrm{a}-1$ & $\mathbf{7 3 . 4}$ & 5 & 14 & 76.7 & 0.6 & 12 \\
MIS 5a-2 & T1a-2 & $\mathbf{8 0 . 9}$ & 5 & 5 & 84.2 & 0.7 & 4 \\
MIS 5a-2 & $\mathrm{N} 2$ & $\mathbf{8 5 . 5}$ & 6 & 7 & 84.5 & 0.8 & 3 \\
MIS 5c-3 & $\mathrm{T} 3$ & $\mathbf{1 0 2 . 6}$ & 6 & 8 & 102.9 & 1 & 3 \\
MIS 5c & $\mathrm{N} 1{ }_{[5 c]}$ & $\mathbf{1 0 8 . 7}$ & 9 & 5 & 105.4 & 1 & 7 \\
\hline
\end{tabular}

ESR $=$ Upper quartile value ( $25 \%$ of all ESR ages are ranked above this value)

$\mathrm{U} / \mathrm{Th}=$ Median of $\mathrm{U} / \mathrm{Th}$ data with initial delta ${ }^{234} \mathrm{U}$ values between 141 and 157 permil 


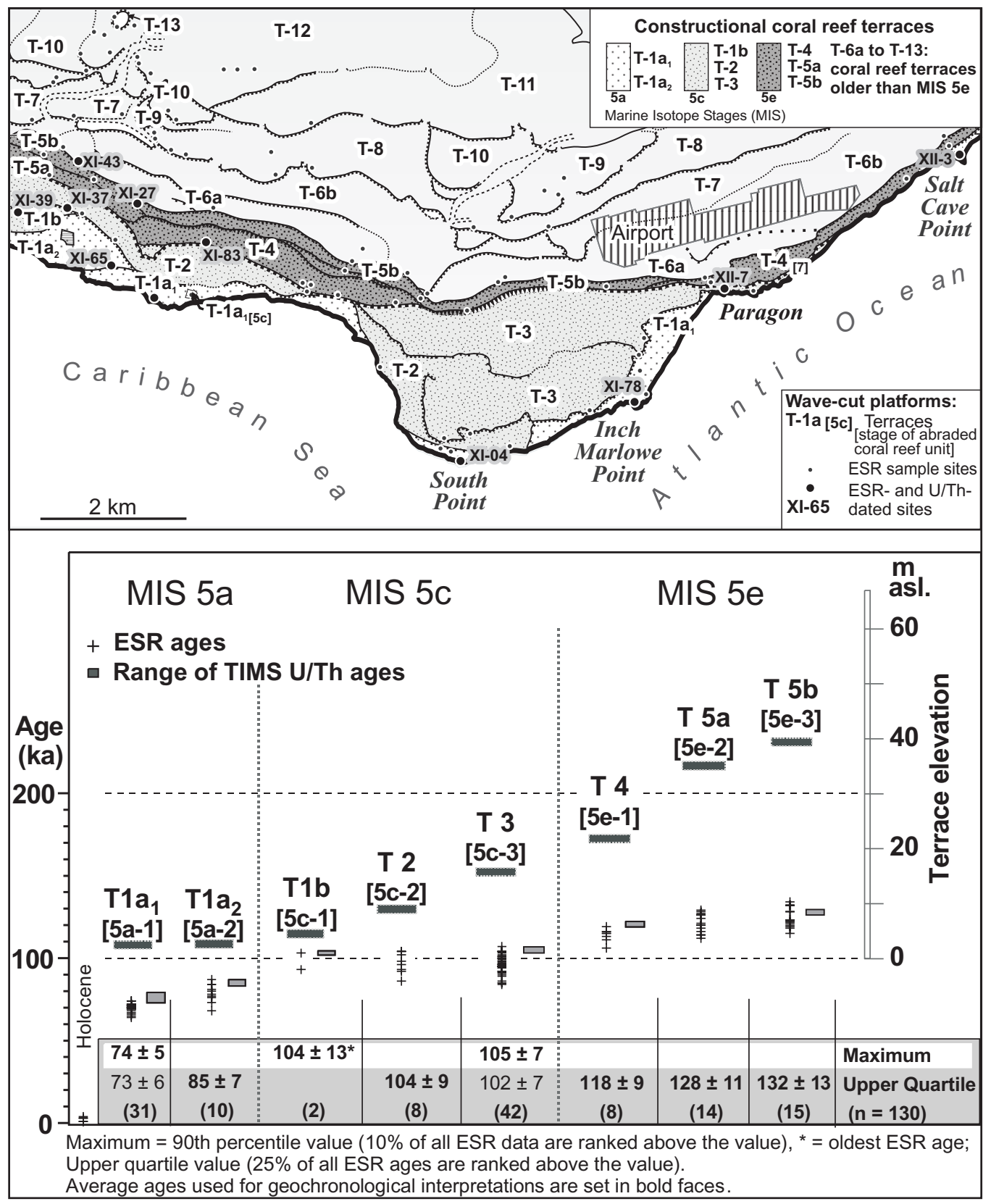

Fig. 11: Coral reef terraces along the southern coast of Barbados with location of ESR and TIMS U/Th dated corals (XI-No. $=$ dated location). TIMS U/Th datings were carried out by E.-K. Potter (Australian National University, Canberra). Details are provided in Schellmann et al. (2004a).

Abb. 11: Korallenriff-Terassen entlang der Südküste von Barbados mit den Entnahmepunkten für die Datierung von Korallen mittels ESR und TIMS U/Th (XI-No. = datierte Lokation). TIMS U/Th-Datierungen wurden von E.-K. Potter (Australian National University, Canberra) durchgeführt. Für weitere Details siehe SCHELLMANn et al. (2004a). 
individual TIMS U/Th ages is not better than that of ESR dating. The best possible resolution of both dating methods is also nicely demonstrated for branches of corals sampled at Batts Rock Bay, west coast of Barbados, that were formed during the two sea level sub-maxima of MIS 5c und MIS 5a. According to this data set, both dating approaches are associated with a relatively high non-systematic spread of ages of a few thousand years.

\subsection{ESR dating of Holocene corals from the Netherlands Antilles (Aruba, Bonaire, Curaçao)}

To further confirm the accuracy of ESR dating, 21 radiocarbon-dated sub-modern, as well as Late and Middle Holocene, coral samples from Tsunami deposits found on Aruba, Bonaire and Curaçao (Netherlands Antilles) were dated by ESR (Fig. 14). The calibrated radiocarbon ages spread between 0 and 3644 years and the ESR ages were between 9 and 3653 yr (not considering the individual uncertainties of each measurement). Despite one sample that is considered an outlier, the ages determined for both methods are consistent within an error range of ca. $250 \mathrm{yr}$. However, most ESR data shows a tendency towards slightly higher values in ages compared to radiocarbon, which were reservoir corrected assuming that $\Delta \mathrm{R}=-49$ (ca. $392 \mathrm{yr}$ ). It is likely that the marine reservoir effect did considerably change in the past and that the assumed $\Delta \mathrm{R}$-value is not representative for all samples. The calibrated radiocarbon ages may hence not automatically represent the "true" age of a sample. The improved quality of ESR dating is also demonstrated by ESR dating of sub-modern corals that were collected alive by the Zoological Museum of Amsterdam University in the year 1920 . For these samples, uncorrected ${ }^{14} \mathrm{C}$ ages were $586 \pm 24$ and 595 \pm 24 , respectively. ESR ages were „recent“

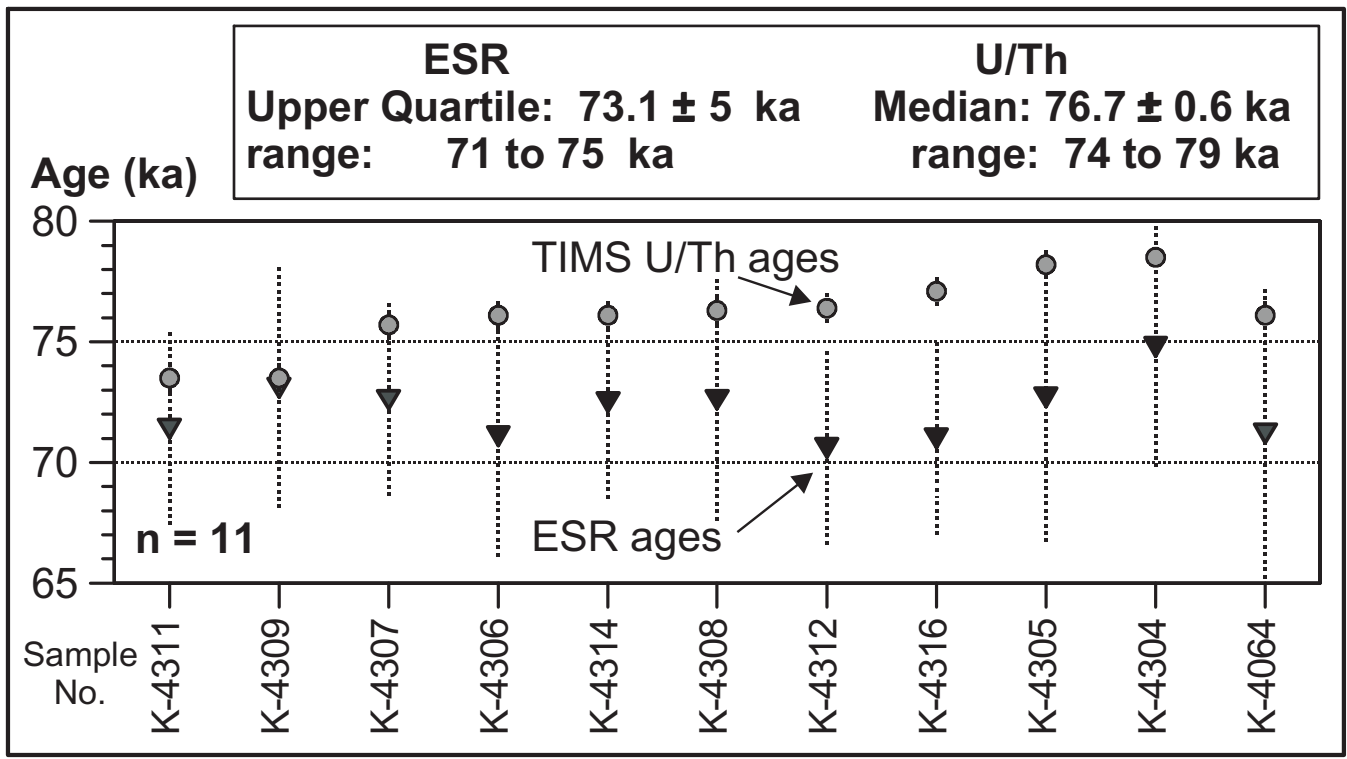

Fig. 12: ESR and TIMS U/Th ages $\left(\delta^{234} \mathrm{U}>141\right.$ and $<157 \%$ ) of coral reef terrace T-1a near Inch Marlowe Point, southern coast of Barbados. See sample site XI-78 in Fig. 11 (slightly modified after Schellmann et al. 2004a).

Abb. 12: ESR und TIMS U/Th-Alter $\left(\sigma^{234} U>141\right.$ and $\left.<157 \%\right)$ der Korallenriffterrasse T-1a bei Inch Marlowe Point an der Südküste von Barbados. Die Lage des Entnahmepunktes XI-78 ist Abb. 12 zu entnehmen (leicht verändert nach SCHELLMANN et al. 2004). 


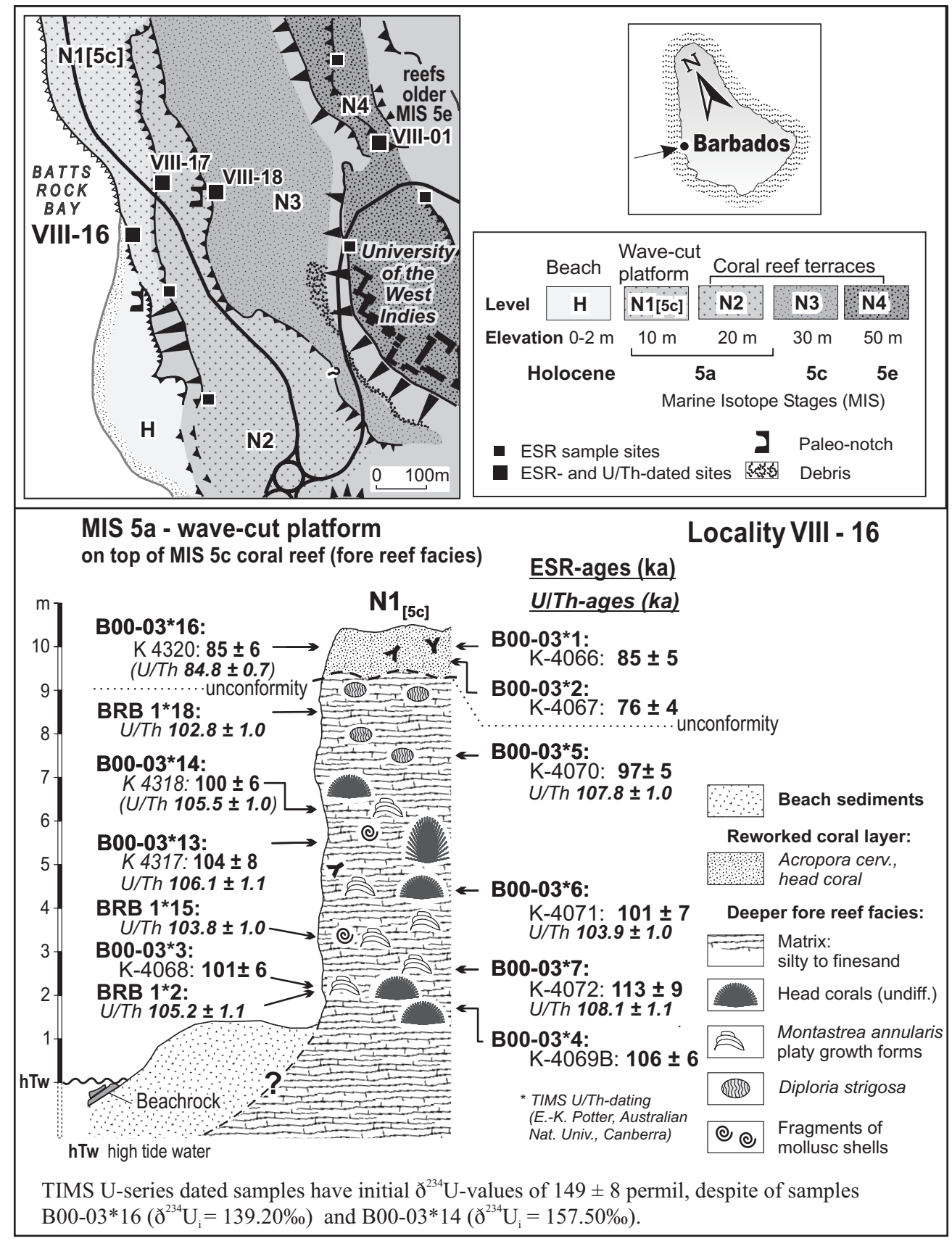

Fig. 13: ESR and TIMS U/Th ages of MIS 5a and MIS 5c coral reefs from Batts Rock Bay. TIMS U/Th datings were carried out by E.-K. Potter (Australian National University, Canberra). Details are provided in SCHELlmann et al. (2004a).

Abb. 13: ESR- und TIMS U/Th-Alter von Korallenriffen (MIS 5a und MIS 5C) von Batts Rock Bay. Die TIMS U/Th-Datierungen wurden von E.-K. Potter (Australian National University, Canberra) durchgeführt. Für weitere Details siehe Schellmann et al. (2004a). 
and $232 \pm 22$ before present ( 1778 AD) (RADTKE et al. 2003: Table 1). Considering the small amplitude of the ESR dating signal from such young samples, it is astonishing that the ESR ages are much closer to the „real“ age of 1920 .

\section{ESR dating of quartz}

\subsection{ESR dating of heated quartz}

As ESR signals in quartz usually decay when heated, heating mechanisms in nature may provide an appropriate means of resetting the geological clock, enabling one to establish the age of the (last) heating. For instance, xenolithic quartz in volcanic rocks in the Eifel region (Germany) was successfully dated with the Al-centre (WodA et al. 2001). In general, the ESR ages were in good agreement with independent age control (Ar-Ar) up to $500 \mathrm{ka}$ (Fig. 15).

Similarly, quartz-rich sediments, which were sufficiently heated by overlying lava flows, can be used to estimate the geological age of the lava flow. Miallier et al. (1994a) showed the potential of $\mathrm{Ti}^{-}$and Al-centres to date sediment baked by a Late Pleistocene lava flow by comparison with red TL and other independent age controls. However, dating attempts of heated quartz from a $\sim 580 \mathrm{ka}$ pumice $\left({ }^{40} \mathrm{Ar} /{ }^{39} \mathrm{Ar}\right)$ showed scattered ESR underestimates for these centres (MiALLIER et al. 1994b), leading to the conclusion that the dating range of ESR is below $500 \mathrm{ka}$ for such materials.

ESR results for heated quartz were recently published by ToyodA et al. (2006). In this study, Al- and Ti-centres were used for ESR dating of Quaternary tephra from Japan, in comparison with red TL and other independent age controls (fission track, K/Ar). Although some degree of consistency could be observed for samples younger than $60 \mathrm{ka}$, the ESR results appeared very scattered, internally (inconsistencies between Al- and Ti-centres) as well as externally (inconsistencies between the ESR and TL data).

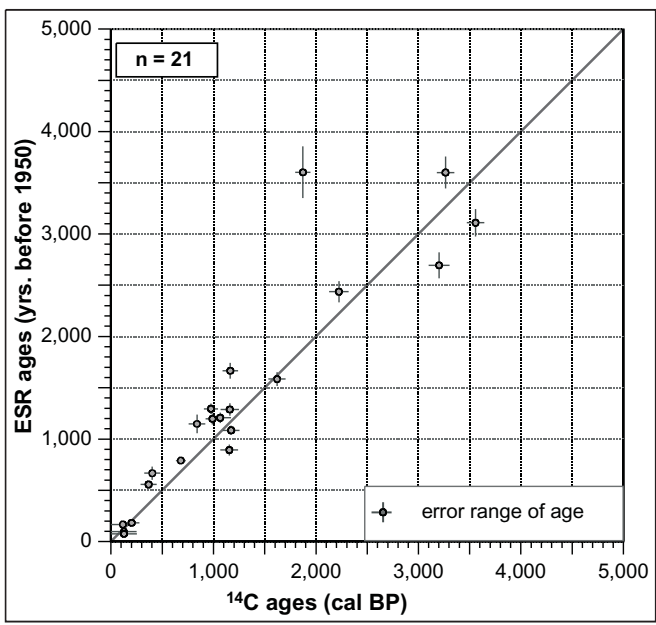

Fig. 14: ESR and radiocarbon ages of Holocene corals from Aruba, Bonaire and Curacao (Netherlands Antilles). Calibrated radiocarbon ages were corrected for marine reservoir effect. Radiocarbon dated coral samples were provided by D. Kelletat \& A. Scheffers (Institut für Geographie, Universität Essen); dating and calibration by B. Kromer (Institut für Umweltphysik, Universität Heidelberg); details in RADTKE et al. (2003).

Abb. 14: ESR- und ${ }^{14} \mathrm{C}$-Alter holozäner Korallen aus Aruba, Bonaire und Curacao (Niederländische Antillen). Die kalibrierten ${ }^{14} \mathrm{C}$-Alter wurden um den marinen Reservoireffekt korrigiert. Die ${ }^{14} \mathrm{C}$-Alter wurden von D. Kelletat \& A. Scheffers (Institut für Geographie, Universität Essen) zur Verfügung gestellt, Datierung und Kalibration durch B. Kromer (Institut für Umweltphysik, Universität Heidelberg). Weitere Details bei RADTKE et al. (2003).

Reported ESR ages of heated quartz are often lower for the Al-centre, in comparison with the Ti-centre. This may be due to different thermal stabilities of Al- and Ti-centres (ToyodA \& IKEYA 1994). Furthermore, high ambient temperatures such as those in geothermal areas may be sufficient to lower the natural ESR signal of volcanic quartz, eventually leading to age underestimates (ToyodA et al. 1995). RiNK (1997) argued that this would lower the ESR dating range of volcanic rocks to around 50-60 ka. Alternatively, age overestimates may result from insufficient signal zeroing of ESR signals before or during the eruption (WODA et al. 2001). Several studies indicate that the 


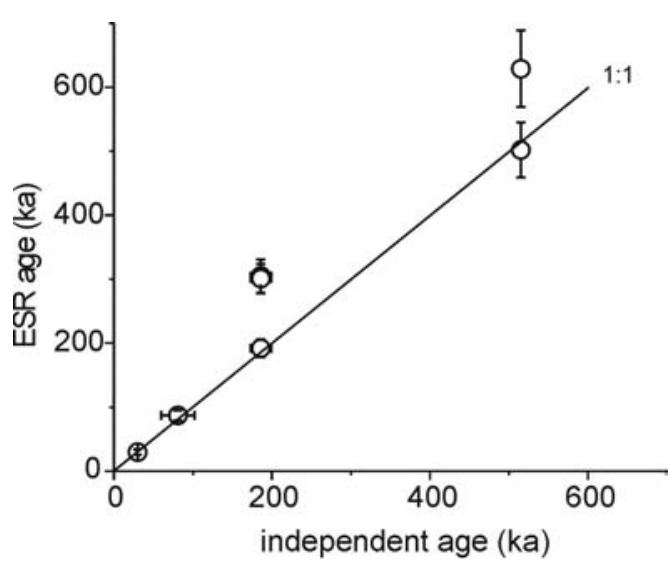

Fig. 15: ESR age plot for samples taken from volcanic deposits in the Eifel region, Germany. Replotted after Woda et al. (2001).

Abb. 15: Darstellung von ESR-Altern aus vulkanischen Ablagerungen der Eifel, Deutschland (aus WodA et al. 2001).

E'-centre can be used to critically reject insufficiently heated samples (FALGUÈRES et al. 1994, WodA et al. 2001).

\subsection{ESR dating of strained quartz}

ESR dating of faults is based on the principle of signal zeroing due to fault activity. Fault movements may strain quartz in fault gouge in such a way that the ESR signals are completely zeroed during faulting. Subsequently, the ESR signal starts to grow again, thus allowing the determination of the geological age of the last fault movement. ESR dating of fault gouge is of particular importance in seismic risk assessment. Generally, fault gouge is dated by the ESR plateau method (BuHAY et al. 1988). The methodology involves the use of several ESR centres (usually E'-, OHC- and Al-centres) from different quartz grain size fractions. The idea is that the smaller the grain size, the more the quartz is affected by strain and the more the geological clock has been reset (Fig. 16).

Usually, the best age estimates are obtained from the smallest grain size fractions (LEE \& Schwarcz 1994). Sometimes however, even the smallest grain size fractions (i.e., around

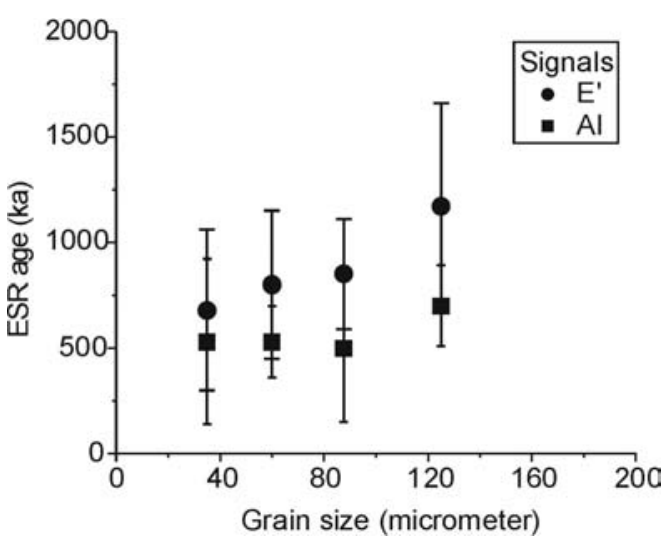

Fig. 16: ESR age plot for fault gouge from the Wangsan Fault (Southern Korea) according to the grain size and the ESR centre used. Note the systematically higher ages for the E'-centre. Replotted after LEE \& YANG (2003).

Abb. 16: ESR Alter aus Proben der Wangsan Störung (Süd Korea) bezogen auf die Korngröße und das genutzte ESR Zentrum. Zu beachten sind die systematisch höheren Alter für das E'-Zentrum (nach LeE \& YANG 2003).

$30 \mu \mathrm{m})$ do not reflect the age of the last fault movement. For instance, this was shown by LEE \& YANG (2003) in a study on ESR dating of the Wangsan Fault in Southern Korea. Here, ESR ages based on the E'- and Al-centres in quartz from fault gouge cluster around 500-600 $\mathrm{ka}$, but the fault gouge is considered to have been lifted to the surface by later fault movements, which were not strong enough to reset the ESR signals. As such, the reported ESR ages are considered to reflect the latest global reactivation of the fault. In some cases, it appears only possible to calculate maximum ages for the last fault reactivation, as shown by LEE $\&$ YANG (2007).

The $\mathrm{E}_{1}$ '-centre is commonly observed in quartz and silica, and has been used to investigate the age of fault movements, heated flint and volcanic ash. However, ESR ages based on this centre should be carefully interpreted because of the possible occurrence of an overlapping unstable signal, the so-called counterfeit $\mathrm{E}_{1}{ }^{6}$ signal (TOYODA \& ScHWARCZ 1994) 

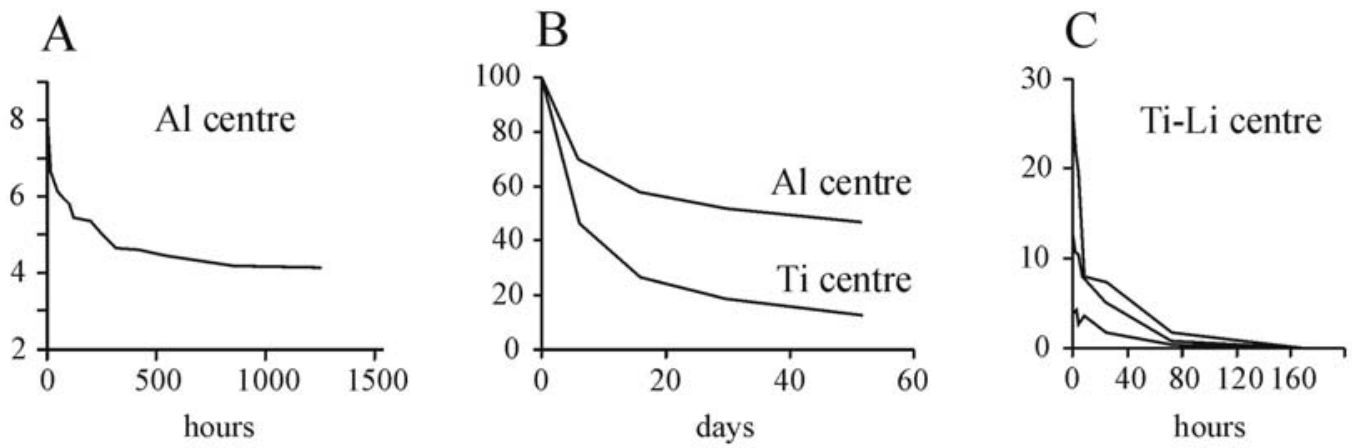

Fig. 17: Simplified bleaching curves for Al- and Ti-centres in quartz. Replotted after A: LAURENT et al. (1998), B: Brumby \& Yoshida (1994) and C: Toyoda et al. (2000). A: UV-lamp, B: natural sunlight, C: halogen lamp.

Abb. 17: Vereinfachte Bleichkurve für die Al- und Ti-Zentren in Quarz. A: nach LaURENT et al. (1998). B: nach Brumby \& Yoshida (1994) und C: nach Toyoda et al. (2000). A: UV-Lampe, B. natürliches Sonnenlicht, C: Halogenlampe.

\subsection{ESR dating of sedimentary quartz}

Quartz grains that are exposed to natural sunlight sufficiently long will have their ESR signals reset to a certain extent during transport, prior to burial (Fig. 17). This important principle forms the basis of ESR dating of sediments. It is one of the most promising sub-disciplines in ESR dating. The specific age range of ESR dating of quartz, possibly up to several Ma, makes sediment dating a potentially very valuable tool, with applications in geology, geography, prehistory and palaeoanthropology. The specific issue in ESR dating of sediments is the extent to which the geological clock is reset to zero, or to a value, which can be determined in the laboratory. Resetting of the geological clock proceeds through sunlight bleaching of ESR centres during transport, prior to burial. Experimental bleaching curves are shown in Fig. 17 for various ESR centres and various artificial light sources. The Al-centre contains an unbleachable residual, whereas Ti-centres can be fully (or to a negligible level) reset. Note that bleaching times are on the order of days to weeks.

\subsubsection{Aeolian sediments}

The most straightforward application of ESR dating of sedimentary quartz is that of aeolian sediments, because of the sunlight bleaching potential. Several studies report reasonable ESR ages for aeolian sand, based on the Alcentre, in the time frame up to several $100 \mathrm{ka}$ (Yokoyama et al. 1985, TANAKA et al. 1995). Since the Al-centre contains an important unbleachable residual with respect to natural sunlight radiation, it is important to mention that the ESR ages reported in these studies are corrected for this residual. The principle of this method is shown in Fig. 18. Recent investigations in ESR dating of aeolian sand using the Al-centre also include Chinese loess deposits (YIN et al. 2007). Although the results show a strong underestimate relative to the independent age control of the loess, the method seems very promising if the residual dose can be determined very accurately.

The problem of residual doses is less pertinent with Ti-related ESR centres because bleaching studies indicate that the ESR signal can be reset completely or at least to a negligible level with respect to deposits older than Late Pleistocene. Recently for instance, it was shown that in- 


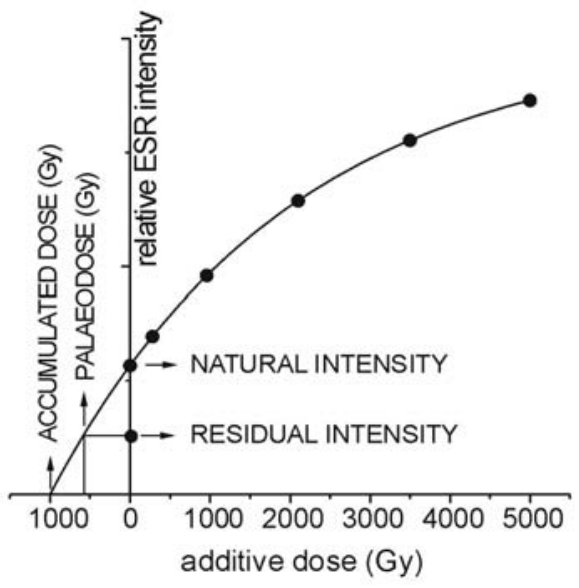

Fig. 18: Correction for the unbleachable residual in ESR dating of quartz sediments using the Al-centre. The residual intensity is measured after prolonged bleaching and this level is used to infer the true palaeodose. Replotted after LAURENT et al. (1998).

Abb. 18: Korrektur unbleichbarer Reste bei der ESR-Datierung von Quarzsedimenten unter Berücksichtigung des Al-Zentrums. Die Restintensität wird nach verlängerter Bleichung gemessen, wobei dieses Niveau zur Bestimmung der Paläostrahlungsrate genutzt wird (nach LAURENT et al. 1998).

dividual quartz grains show non-existing or only very small residual Ti-related doses in an Egyptian desert sand deposit (Fig. 19; BEERTEN \& Stesmans 2005).

The potential and problems of multiple grain ESR dating using Ti-centres has been outlined in BEERTEN et al. (2006) for Australian sand dunes up to $350 \mathrm{ka}$. Large differences are often encountered for individual Ti-related sub-centres in the regenerative dose method, but it is not clear yet whether this is due to sensitivity changes or not. ESR ages based on Ti-H centres seem to underestimate the OSL ages for this profile, whereas the opposite is true for Ti-Li centres. Comparisons with the additive dose method are often hampered by improper dose response showing inflexion points (BEERTEN et al., in press).

The potential and problems of single grain ESR dating using Ti-centres has been outlined in Beerten \& Stesmans (2007). The first results

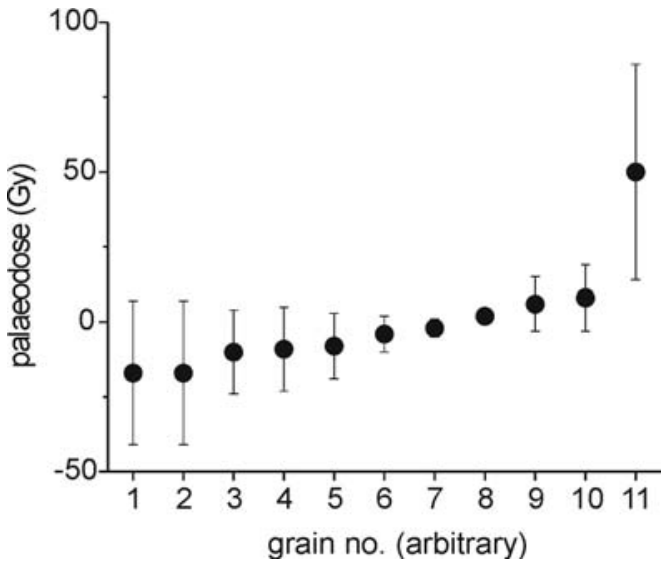

Fig. 19: ESR equivalent dose plot for Ti-centres from individual grains taken from a modern desert surface deposit, Eastern Desert, Egypt. Except for one grain (no. 11), all values are consistent with the expected dose of 0 Gy. Replotted after BEERTEN \& Stesmans (2005).

Abb. 19: Darstellung der ESR Äquivalent Dosis für Ti-Zentren, gemessen an Einzelkörner moderner Oberflächenablagerungen aus der Östlichen Wüste, Ägypten. Mit Ausnahme einer Messung (Korn Nr. 11) zeigen alle Messungen konsistente Ergebnisse um den erwarteten Wert von 0 Gy (nach BEERTEN \& Stesmans 2005).

of this new approach in ESR dating are very promising, but appropriate adaptations in instrumentation and equipment are necessary to make it more flexible and user friendly.

\subsubsection{Fluvial and estuarine sediments}

ESR dating has been shown to be a useful tool for establishing geochronological frameworks for fluvial and estuarine/marine deposits. Despite proven difficulties with bleaching residuals related to the Al-centre in quartz, this specific ESR centre has been used in many studies to date sedimentary sequences spanning the whole Quaternary period, and even up to the Miocene. A famous example of ESR dating of a fluvial terrace staircase is that from the Somme Basin, France, where consistent ESR results could be obtained relative to biostratigraphi- 
cal, archaeological and palaeomagnetic data (Fig. 20; Laurent et al. 1998, Antoine et al. 2000). The same methodology, i.e. ESR of the Al-centre with subtraction of the unbleachable residual, has been used for other terrace staircases as well, with promising results (VOINCHET et al. 2004, BAHAin et al. 2007, Tissoux et al. 2007). The Al-centre even has the potential to date Plio-Miocene estuarine deposits, as was shown by LAURENT et al. (1998). In this study, a consistent ESR dating pattern for deposits from the Tiglian up to the Tortonian (around 8-9 Ma) was obtained.

The quality of the ESR ages from these studies is guaranteed to some extent by bleaching experiments on recent fluvial deposits. LAURENT et al. (1998) and VoINCHET et al. (2003, 2007) showed that the Al-related ESR signal in quartz is at or very close to the unbleachable residual

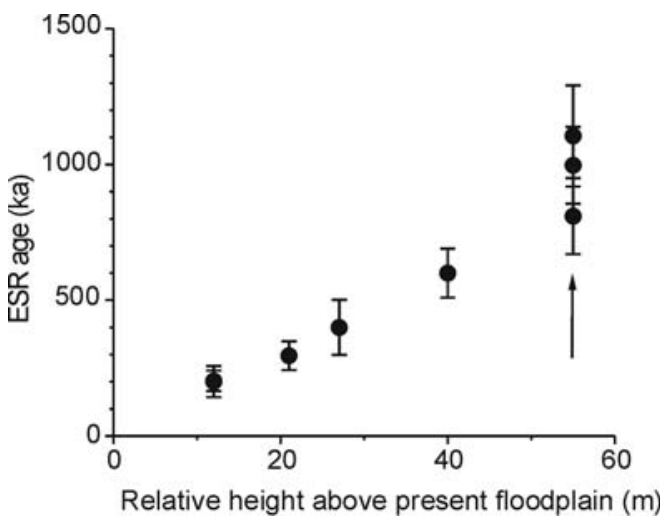

Fig. 20: ESR dating of the River Somme terrace staircase. Replotted from data in LAURENT et al. (1998) and ANTOINE et al. (2000). Only ESR ages on quartz are given. Other age control is available for the terrace sequence. The highest level in this diagram is supposed to be older than the B/M boundary, based on palaeomagnetic measurements. This is confirmed by the ESR dates (see arrow).

Abb. 20: ESR-Daten aus der Somme Terrassenstufe. (nach LaURENT et al. 1998 und ANTorne et al. 2000). Es sind nur Alter von Datierungen an Quarz dargestellt. Für die Terrassensequenz sind auch andere Alterskontrollen möglich. Für die oberste Stufe wird durch paläomagnetische Altersbestimmung ein Alter älter als die B/M Grenze angenommen. Dies wird durch die ESR-Daten bestätigt (s. Pfeil). level for various modern (i.e. zero-age) fluvial samples. Another point that should be kept in mind when evaluating such ESR dating results, is the targeted age range. Whereas, due to the slow bleaching behaviour, the Al-centre is probably inappropriate for detailed chronologies in the Late and late Middle Pleistocene, it may be a valuable tool for rough age determinations of extended Early Pleistocene and Pliocene sedimentary sequences, especially if other age-markers or suitable materials for dating are absent. Therefore, the highest potential of the Al-centre could be situated in the Tertiary, where a rough assignment to chronozones could be sufficient to tune estuarine/marine sedimentary sequences to the global sequencestratigraphic timescale.

However, some fundamental issues in ESR dating using the Al-centre remain ambiguous. First, the determination of the bleaching residual usually proceeds through artificial bleaching experiments using some kind of 'solar simulator'. Up to the present, it is unclear how the irradiation spectrum of the solar lamp influences the magnitude of this residual. Second, the accuracy of the results is only guaranteed if this bleaching residual is a fixed value, in terms of absolute ESR defect concentration, as was pointed out by BRUMBY \& Yoshida (1994b).

Lately, more attention has been paid to the use of Ti-centres for ESR dating of fluvial deposits from terrace staircases as well. A comparative study between ESR dating results of Al- and Ticentres recently showed that both species have a large potential in geochronological studies (Tissoux et al. 2007). However, from detailed studies it has become clear that individual ages at the single-grain scale may vary considerably if Ti-centres are used (BEERTEN et al. 2003). Tirelated ESR centres may even contain a small but detectable unbleachable residual, as was recently shown with artificial bleaching experiments on fluvial quartz (VoINCHET et al. 2007).

\subsubsection{Glacial sediments}

Grinding of quartz grains may occur not only 
in a fault-related context, but also in some sedimentary environments. Together with sunlight bleaching, such grinding mechanisms could be an effective zeroing mechanism in ESR dating of glacially derived sediments. As such, the Ge-related impurity centre in quartz appears to generate promising results, e.g. in dating Pleistocene glaciations in Central Asia (ZHAO et al. 2006, ZHOU et al. 2006).

Whereas the basis for this specific ESR approach was laid by methodological studies on the behaviour of Ge-centres with respect to sunlight bleaching and pressure (TANAKA et al. 1985, Buhay et al. 1988, Ye et al. 1998), some fundamental points remain unclear. For instance, although growing with small artificial irradiation doses, it appears very difficult to find a natural Ge signal in quartz, as has been pointed out already by RINK (1997). The implication of this observation could be that the Ge centre is not stable at average burial temperatures.

\subsection{General remarks}

Various methodological issues are common to all types of quartz, irrespective of the geological context. Generally, the additive dose method is used to determine the equivalent dose in quartz. However, sometimes this approach may lead to large uncertainties for samples with a relatively large equivalent dose. In such cases, it would be advantageous to use the regenerative dose method. For ESR centres in quartz, artificial heating may be the most efficient and comfortable way of annealing the signal prior to regenerative dosing. Although this mechanism is not the annealing mechanism in sedimentary environments, this approach is currently being tested for ESR dating of sediments using Ti-related centres (BEerten et al. 2006). A major concern here is the possible presence of sensitivity changes (i.e. an alteration of the radiation-sensitivity of the ESR-signal) due to the heating step. Less comfortable in experimental terms, but much more related to the zeroing mechanism in sedimentary environments, is optical bleaching of ESR centres prior to administering the regenerative dose. First results of this approach were recently published for Al-centres in loess (YIN et al. 2007). Unfortunately, the ESR dose response is often found to be problematic in various quartz samples. Sometimes, strong inflexion points are found in the dose response of the Ti-centre and the Al-centre. There are also observations on non-monotonic linear growth of Ti- and Ge-centres, indicating an ESR signal decrease with very high doses of several 1000 Gy (WODA \& WAGNER, in press).

\section{ESR dating of some other materials (speleothems, foraminifera, tooth enamel)}

ESR dating has also been applied to a wide variety of other materials with great importance, especially in palaeoclimatological and archaeological contexts. The most common applications in this framework include speleothems, foraminifera, and tooth enamel.

Many ESR papers have published combined ESR and U-series dating results of speleothems (stalagmites, stalactites), which generally show good agreement. A detailed review is given by Rink (1997: 990f.). Nevertheless, as stated by Pirouelle et al. (2007), further research is still needed about the best analytical routine for obtaining correct $\mathrm{D}_{\mathrm{E}}$ values, which include systematic dating applications coupled with other (e.g. U-series) dating methods. However, as GRÜN (2007: 1512) stated, U series dating of speleothems and other secondary carbonates is much cheaper, faster and more accurate than ESR.

Studies on ESR dating of planctonic foraminifera from a deep-sea sediment core by Mudelsee et al. (1992) show good agreement with delta ${ }^{18} \mathrm{O}$ stratigraphy. The authors see the possibility to date planctonic foraminifera up to approx. $800 \mathrm{ka}$ by using the ESR signal at $g=2.0036$. More recently, Hoffmann et al. (2001) stated that foraminifera could be dated up to $190 \mathrm{ka}$, just when using the $\mathrm{CO}_{2}^{-}$-signal at $\mathrm{g}=2.0006$. All in all, more studies on wellstratified deep sea cores in combination with independent age controls are needed to show 
the potential and the limits of ESR dating of foraminifera.

Lately, ESR dating on human tooth enamel, in conjunction with laser ablation U-series dating, has become an important method for determining the age of human remains back to about 200 to $300 \mathrm{ka}$, beyond the time range of the ${ }^{14} \mathrm{C}$ dating method (e.g. GRÜN 2006, 2007; SorESSI et al. 2007). Most recently, GRÜN (2006) gives a detailed description of the ESR dating method itself in application on human teeth, which includes application examples and comparisons with other dating results $\left({ }^{14} \mathrm{C}\right.$, U-series, AAR). In addition, HAMEAU et al. (2007) see a good agreement of coupled ESR/Uranium-series dating of Middle Pleistocene Rhinocerus and Tapirus tooth enamel on East Java associated with lithic artefacts, which seems to provide a new geochronological framework of human occupation in South-East Asia. Details on ESR dating of teeth are summarized by GRÜN (2006) and RinK (1997).

There are further materials, e.g. travertines, calcretes or bones, which have been the object of ESR dating. However, the ages are less reliable due to complex Uranium uptake histories, to problems of recrystallisations or to carbonate impurities, which often lead to age underestimations (e.g. RINK 1997; GRÜN 2007).

\section{Summary and outlook}

Due the methodological advances of the past decade, ESR dating has become an important geochronological method, especially for dating deposits such as coral reefs and beach ridges as well as quartz from different geological settings. The reliability of ESR dating of carbonates was proven by direct comparison with other dating methods such as radiocarbon and TIMS U/Th. ESR dating of Holocene corals shows accuracy similar to radiocarbon dating when all sources of uncertainty are fully considered. ESR dating of Pleistocene corals allows not only to distinguish between MIS 1, 5, 7, 9, 11 and 13 deposits, but also between sub-stages $5 \mathrm{e}_{3 / 2}, 5 \mathrm{e}_{1}, 5 \mathrm{c}, 5 \mathrm{a}_{1}$ and $5 \mathrm{a}_{2}$. The average error of ESR dating of corals is about 5-
$8 \%$. Late Pleistocene corals can be dated with a similar accuracy as with TIMS U/Th in this time range. The advantage of ESR, however, is that the upper dating limit for corals is probably above 500,000 yr. If diagenesis could be excluded, dating of coral with an age of several million years should be feasible from the physical point of view.

The resolution of ESR dating of molluses and gastropods is with 10-15\% much lower. Additionally, ages tend to scatter quite substantially, which causes the need to carry out several datings for the same stratigraphic unit to allow accurate geochronological interpretation. Usually it is then possible to correlate layers to certain interglacials periods such as MIS 1, 5, 7 and 9. The high scatter associated with ESR ages of molluscs and gastropods is most likely related to yet not identified problems in palaeodose determination, since problems in dose rate apparently do not account for the scatter.

The examples shown in this paper demonstrate that ESR can be successfully applied to date quartz in various geological contexts. It should be clear that the large age range of ESR dating (up to several Ma), especially in relation to OSL dating (up to several 100 ka), underlines its important position next to other geochronological techniques. However, there are several issues that need further consideration. The accuracy with which the palaeodose can be determined is highly dependent on the degree of resetting of the ESR signal. Some examples show that incomplete resetting could undermine the reliability of the method. Therefore, it is important to incorporate criteria (external and internal) to evaluate the completeness of the zeroing process in nature, such as the plateau method for fault gouge and the use of multiple ESR centres and/or single grain measurements for sediment dating. Cross-checking of the results with independent age control is another crucial step in the development of a reliable ESR dating method. In the case of sediments, reference ages may be provided by luminescence dating (OSL, TL) for Late Pleistocene and in favourable circumstances even Middle Pleis- 
tocene deposits. Similarly, ESR dating results of tephra layers could be evaluated against red TL measurements.

The reliability of the palaeodose determination method, purely experimentally, is another concern in ESR dating of quartz. Results of the regenerative dose method and additive dose method should be compared very carefully and a proper annealing mechanism should be looked for in the regenerative dose method (UV-bleaching for sedimentary quartz; thermal annealing for heated quartz). At present, experimental techniques in ESR dating of quartz produce relatively large errors (usually around $15 \%$ ). In part, this may be related to the dose determination method (i.e. the additive dose technique in the case of older samples), but it is important to verify if intrinsic properties of ESR defects could be the cause of such large errors (i.e. inflexion points). In general, it is believed that the regenerative dose technique may produce much more precise results if there are no sensitivity changes.

There are even more materials, which have the potential for a dating by ESR, however the most reliable applications until now or in the near future seem to be coupled ESR/U-series dating of tooth enamel and perhaps speleothems. A great potential is inherited in ESR dating of foraminifera, which only needs more applications.

In summary, it is clear that the development of the ESR method is far from being complete and it is important to carry out methodological investigations before the full potential of the method can be used.

\section{Acknowledgements}

We thank the German Research Foundation (Deutsche Forschungsgemeinschaft, DFG) (grants Ra 383/6-1 to 6-3, Sche 465/2-1) and the Universities of Bamberg, Cologne and Essen for supporting the studies financially during the past years. We are grateful to the Centre of Nuclear Medicine, University of Düsseldorf, for support with ${ }^{60} \mathrm{Co}$ irradiation.
Special thanks to Dr. Bernd Kromer (University of Heidelberg) and the Institute of Physics (University of Erlangen) for the Radiocarbon data. We are also grateful to W.J. Rink and an unknown reviewer for their helpful comments. Last, but not least, we would like to say many thanks to Dr. Frank Preusser (University of Bern), who translated large parts of the manuscript, and to Mrs. Karen Schneider (University of Cologne) for polishing the English of the manuscript.

\section{References}

Antoine, P., Lautridou, J.P. \& Laurent, M. (2000): Long-term fluvial archives in NW France: response of the Seine and Somme rivers to tectonic movements, climatic variations and sea-level changes. - Geomorphology, 33: 183-207.

Bahain, J.J., Falguères, C., Laurent, M., VoinChet, P., Dolo, J.M., Antolne P. \& Tuffreau, A. (2007): ESR chronology of the Somme River Terrace system and first human settlements in Northern France. - Quaternary Geochronology, 2: 356-362.

Barabas, M., Bach, A., Mudelsee, M. \& Mangini, A. (1992): General properties of the paramagnetic centre at $\mathrm{g}=2.0006$ in carbonates. - Quaternary Science Reviews, 11: 165-171.

Beerten, K. \& Stesmans, A. (2005): Single quartz grain ESR dating of a contemporary desert surface deposit, Eastern Desert, Egypt. - Quaternary Science Reviews, 24: 223-231.

Beerten, K. \& Stesmans, A. (2007): ESR dating of sedimentary quartz: possibilities and limitations of the single grain approach. - Quaternary Geochronology, 2: 373-380.

Beerten, K., Pierreux, D. \& Stesmans, A. (2003): Towards single grain ESR dating of sedimentary quartz: first results. - Quaternary Science Reviews, 22: 1329-1334.

Beerten, K., Lomax, J., Clémer, K., Stesmans, A. \& RadtKe, U. (2006): On the use of Ti centres for estimating burial ages of Pleistocene sedimentary quartz: Multiple-grain data from Australia. - Quaternary Geochronology, 1: 151-158.

Beerten, K., Rittner, S., Lomax, J. \& Radtke, U. (in press): Dose recovery tests using Ti-related ESR signals in quartz: first results. - Quaternary Geochronology. 
Blackwell, B.A.B. (2006): Electron Spin Resonance (ESR) dating in Karst environments. - Acta Carsologica, 35/2: 123-153.

Brumby, S. \& Yoshida, H. (1994a): ESR dating of mollusc shell: investigations with modern shell of four species. - Quaternary Science Reviews, 13: 157-162.

Brumby, S. \& YoshidA, H. (1994b): An investigation of the effect of sunlight on the ESR spectra of quartz centres: implications for dating. - Quaternary Science Reviews 13, 615-618.

Buhay, W.M., Schwarcz, H.P. \& Grün, R. (1988): ESR dating of fault gouge: the effect of grain size. - Quaternary Science Reviews, 7: 515-522.

Engin, B., Kapan-Yeșilyurt, S., Tanner, G., Demirtaș H. \& EkEn, M. (2006): ESR dating of Soma (Manisa, West Anatolia - Turkey) fossil gastropoda shells. - Nuclear Instruments and Methods in Physics Research B, 243: 397-406.

Falguères, C., Yokoyama, Y. \& Miallier, D. (1994): Stability of some centres in quartz. - Nuclear Tracks and Radiation Measurements, 18: 155161.

GRÜN, R. (1985): Beiträge zur ESR-Datierung. - Sonderveröffentlichungen des Geologischen Instituts der Universität zu Köln, 59: 1-157.

GRÜN, R. (1989a): Electron Spin Resonance (ESR) dating. - Quaternary International, 1: 65-109.

GRÜN, R. (1989b): Die ESR-Altersbestimmungsmethode. - Heidelberg, Berlin (Springer).

GRÜN, R. (1990): Dose response of the paramagnetic centre at $\mathrm{g}=2.0007$ in corals. - Ancient TL, 8: 20-22.

GRÜN, R. (2006): Direct dating of Human Fossils. - Yearbook of Physical Anthropology, 49: 2-48.

GRÜN, R. (2007): Electron Spin Resonance Dating. - In: Elias, S.A. (ed.): Encyclopedia of Quaternary Science, Vol. 2: 1505-1516; Amsterdam (Elsevier).

Grün, R. \& Katzenberger-Apel, O. (1994): An alpha irradiator for ESR dating. - Ancient TL, 12: 35- 38 .

Grün, R., Radtke, U. \& OMURA, A. (1992): ESR and U-series analyses on corals from Huon Peninsula, New Guinea. - Quaternary Science Reviews, 11: 197-202.

Hameau, S., Falguéres, C., Bahain, J.J., Sémah, F., SÉmah, A.M., \& Dolo, J.M. (2007): ESR dating in Song Terus cave (East Java, Indonesia). - Quaternary Geochronology, 2: 398-402.

Hoffmann, D., Woda, C., Strobl, Ch. \& Mangini, A. (2001): ESR-Dating of the Arctic sediment core PS1535 dose-response and thermal behaviour of the $\mathrm{CO}_{2}{ }^{-}$signal in foraminifera. - Quaternary Science Reviews, 20: 1009-1014.

IKeYA, M. (1975): Dating a stalactite by electron paramagnetic resonance. - Nature, 255: 48-50.

IKEYA, M. (1993): New applications of Electron Spin Resonance. Dating, dosimetry and microscopy. - Singapore.

Ikeya, M. \& Ohmura, K. (1981): Dating of fossil shells with electron spin resonance. - Geology, 89: $247-251$.

Ikeya, M. \& OHMURA, K. (1983): Comparison of ESR ages of corals from marine terraces with ${ }^{14} \mathrm{C}$ and $230 \mathrm{Th} / 234 \mathrm{U}$ ages. - Earth and Planetary Science Letters, 65: 3438.

Jonas, M. (1997): Concepts and methods of ESR dating. - Radiation Measurements, 27: 943-973.

KATZENBERger, O. (1989): Experimentelle Untersuchungen zur ESR-Datierung von Molluskenschalen. - Sonderveröffentlichungen des Geologischen Institutes der Universität zu Köln, 72.

Katzenberger, O. \& Willems, N. (1988): Interferences encountered in the determination of $\mathrm{AD}$ of mollusc samples. - Quaternary Science Reviews, 7: 485-489.

Kinoshita, A., Karmann. I., da Cruz, F.W. (Jr.), GraefF, C.F.O. \& Baffa, O. (2005): K-band ESR spectra of calcite stalagmites from southeast and south Brazil. - Applied Radiation and Isotopes, 62: 247-250.

Laurent, M., Falguères, C., Bahain, J.J., Rousseau, L. \& VAN Vliet Lanoé, B. (1998): ESR dating of quartz extracted from Quaternary and Neogene sediments: method, potential and actual limits. - Quaternary Science Reviews, 17: 1057-1062.

Lee, H.K. \& Schwarcz, H.P. (1994). Criteria for complete zeroing of ESR signals during faulting of the San Gabriel fault zone, Southern California. - Tectonophysics, 235: 317-337.

LEE, H.K. \& YANG, J.S. (2003): ESR dating of the Wangsan fault, South Korea. - Quaternary Science Reviews, 22: 1339-1343.

LeE, H.K. \& YANG, J.S. (2007): ESR dating of the Eupchon fault, South Korea. - Quaternary Geochronology, 2: 392-397.

Lyons, R. (1987): Alpha/gamma response of calcite speleothems as determined by nuclear accelerator techniques. - Fifth Specialist Seminar on TL and ESR dating, 6-10 July 1987, Abstract; Cambridge.

Miallier, D., Sanzelle, S., Falguères, C., Faïn, J., Montret, M., Pilleyre, Th., Soumana, S., Laurent, M., Camus, G. \& De Goër de Hervé, A. (1994a): Intercomparisons of red TL and ESR 
signals from heated quartz grains. - Radiation Measurements, 23: 143-153.

Miallier, D., Faĩn, J., Sanzelle, S., Pilleyre, Th., Montret, M., Soumana, S. \& Falguères, C. (1994b). Attempts at dating pumice deposits around $580 \mathrm{ka}$ by use of red TL and ESR of xenolithic quartz inclusions. - Radiation Measurements, 23: 399-404.

MalmberG, R. \& RadtKe, U. (2000): The $\alpha$-efficiency of corals and its importance for ESR-dating. - Radiation Measurements, 32: 747-750.

Molodkov, A. (1993): ESR-Dating of non-marine mollusc shells. - Applied Radiation and Isotopes, 44: 145-148.

Molodkov, A., Dreimanis, A., Aboltinš \& Raukas, A. (1998): The ESR age of portlandia arctica shells from glacial adeposits of central lativa: an answer to a controversy on the age and genesis of their enclosing sediments. - Quaternary Geochronology, 17: 1077-1094.

Mudelsee, M., Barabas, M. \& Mangini, A. (1992): ESR dating of the Quaternary deep-sea sediment core RC17-177. - Quaternary Science Reviews, 11: 181-189.

Pirouelle, F., Bahain, J.J., Falguères, C. \& Dolo, J.M. (2007): Study of the effect of a thermal treatment on the $\mathrm{D}_{\mathrm{E}}$ determination in ESR dating of speleothems. - Quaternary Geochronology, 2: 386-391.

Prescott, J.R. \& Hutton, J.T. (1994): Cosmic ray contributions to dose rates for luminescence and ESR dating: large depths and long-term time variations. - Radiation Measurements, 23: 497-500.

RADTKE, U. (1985): Zur zeitlichen Stellung mariner Terrassen auf Fuerteventura (Kanarische Inseln). - Kieler Geographische Schriften, 62: 73-95.

RadtKe, U. (1988): How to avoid useless Radiocarbon dating. - Nature, 333: 307-308.

RadtKe, U. (1989): Marine Terrassen und Korallenriffe - Das Problem der quartären Meeresspiegelschwankungen. Erläutert an Fallstudien aus Chile, Argentinien und Barbados. - Düsseldorfer Geographische Schriften, 27: 245 S.

RAdTKE, U. \& GRÜN, R. (1988): ESR dating of corals. - Quaternary Science Reviews, 7: 465-470.

Radtke; U. \& Schellmann, G. (2005): Timing and magnitude of sea level change during MIS 5 derived from Barbados coral reef terraces: a critical literature review and new data. - Journal of Coastal Research, SI 42: 52-62.

Radtke, U., Grün, R. \& Schwarcz, H.P. (1988): Electron spin resonance dating of the Pleisto- cene coral reef tracts of Barbados. - Quaternary Research, 29: 197-215.

Radtke, U., Hennig, G.J., Linke, W. \& MüngersDORF, J. (1981): ${ }^{230} \mathrm{Th} / 234 \mathrm{U}$ and ESR-dating of fossil shells in Pleistocene marine terraces (Northern Latium, Central Italy). - Quaternaria, 23: 37-50.

Radtke, U., Schellmann, G., Scheffers, A., Kelletat, D., Kasper, H.U. \& Kromer, B. (2003): Electron Spin Resonance and Radiocarbon dating of coral deposited by Holocene tsunami events on Curaçao, Bonaire and Aruba (Netherlands Antilles). - Quaternary Science Reviews, 22: 1309-1315.

RINK, W. J. (1997): Electron Spin Resonance (ESR) Dating and ESR applications in Quaternary science and archaeometry. - Radiation Measurements, 27: 975-1025.

Schellmann, G. (1998): Jungkänozoische Landschaftsgeschichte Patagoniens (Argentinien). Andine Vorlandvergletscherungen, Talentwicklung und marine Terrassen. - Essener Geographische Arbeiten, 29: $216 \mathrm{~S}$.

Schellmann, G. \& Kelletat, D. (2001): Chronostratigraphische Untersuchungen litoraler und äolischer Formen und Ablagerungen an der Südküste von Zypern mittels ESR-Altersbestimmungen an Molluscen- und Landschneckenschalen. - Essener Geographische Arbeiten, 32: 75-98.

Schellmann, G. \& Radtke, U. (1999): Problems encountered in the determination of dose and dose rate in ESR dating of mollusc shells. - Quaternary Science Reviews, 18: 1515-1527.

Schellmann, G. \& RadtKe, U. (2000): ESR dating stratigraphically well-constrained marine terraces along the Patagonian Atlantic coast (Argentina). - Quaternary International, 68-71: 261-273.

Schellmann, G. \& Radtke, U. (2001): Progress in ESR dating of Pleistocene corals - a new approach for $\mathrm{D}_{\mathrm{E}}$ determination. - Quaternary Science Reviews, 20: 1015-1020.

Schellmann, G. \& Radtke, U. (2003): Die Datierung litoraler Ablagerungen (Korallenriffe, Strandwälle, Küstendünen) mit Hilfe der Elektronen-Spin-Resonanz-Methode (ESR). - Essener Geographische Arbeiten, 35: 95-113.

Schellmann G. \& RadtKe, U. (2004a): The marine Quaternary of Barbados. - Kölner Geographische Schriften, 81; 137 pp.

Schellmann, G. \& RadtKe, U. (2004b): A revised morpho- and chronostratigraphy of the Late and Middle Pleistocene coral reef terraces on South- 
ern Barbados (West Indies). - Earth-Science Reviews, 64: 157-187.

Schellmann, G. \& RadtKe, U. (2007): Zur ESRDatierung holozäner und jungpleistozäner Muschelschalen - aktuelle Möglichkeiten und Grenzen. - Bamberger Geogr. Schr., 22: 113152; (in press).

Schellmann, G., Radtke, U., Potter, E.-K., Esat, T. M. \& McCulloch, M.T. (2004a): Comparison of ESR and TIMS U/Th dating of marine isotope stage (MIS) 5e, 5c, and 5a coral from Barbados - implications for palaeo sea-level changes in the Caribbean. - Quaternary International, 120: 41-50.

Schellmann G., Radtke, U., Scheffers, A., Whelan F. \& Kelletat, D. (2004b): ESR dating of coral reef terraces on Curaçao (Netherlands Antilles) with estimates of Younger Pleistocene sea level elevations. - Journal of Coastal Research, 20: 947-957.

SkinNer, A.R. \& SHAwl, C.E. (1994): ESR dating of terrestrial Quaternary shells. - Quaternary Science Reviews, 13: 679-684.

SkINNER, A.R. (2000): ESR dating: is it an 'experimental' technique? - Applied Radiation and Isotopes, 52: 1311-1316.

Soressi, M., Jones, H.L., Rink, W.J., Maureille, B. \& Tillier, A.-M. (2007): The Pech-de-l'Azé I Neandertal child: ESR, uranium-series, and AMS ${ }^{14} \mathrm{C}$ dating of its MTA type B context. - Journal of Human Evolution, 52: 455-466.

Tanaka, K., Machette, M.N., Crone, A.J. \& BowMAN, J.R. (1995): ESR dating of aeolian sand near Tennant Creek, Northern Territory, Australia. - Quaternary Science Reviews, 14: 285-293.

TanaKa, T., Sawada, S. \& Ito, T. (1985): ESR dating of Late Pleistocene near-shore and terrace sands in Southern Kanto, Japan. - In: IkeYA, M. \& Miki, T. (eds.): ESR Dating and Dosimetry. Ionics: 275-280; Tokyo.

Thompson, W.G. \& Goldstein, S.L. (2005): Opensystems coral ages reveal persistent suborbital sea-level cycles. - Science, 308: 401-404.

Tissoux, H., Falguères, C., Voinchet, P., Toyoda, S., Bahain, J.J. \& Despriée, J. (2007). Potential use of Ti-center in ESR dating of fluvial sediment. - Quaternary Geochronology, 2: 367-372.

ToyodA, S. \& IKEYA, M. (1994). ESR dating of quartz with stable component of impurity centers. - Quaternary Science Reviews, 13: 625-628.

Toyoda, S. \& Schwarcz, H.P. (1997). Counterfeit $\mathrm{E}_{1}$ ' signal in quartz. - Radiation Measurements, 27: 59-66.
Toyoda, S., Goff, F., Ikeda, S. \& Ikeya, M. (1995): ESR dating of quartz phenocrysts in the El Cajete and Battleship Rock Members of Valles Rhyolite, Valles Caldera, New Mexico. - Journal of Volcanology and Geothermal Research, 67: 29-40.

Toyoda, S., Voinchet, P., Falguères, C., Dolo, J.M. \& LAURENT, M. (2000): Bleaching of ESR signals by the sunlight: a laboratory experiment for establishing the ESR dating of sediments. Applied Radiation and Isotopes, 52: 1357-1362.

Toyoda, S., Tsukamoto, S., Hameau, S., Usui, H. \& Suzuki, T. (2006): Dating of Japanese Quaternary tephras by ESR and luminescence methods. - Quaternary Geochronology, 1: 320-326.

Voinchet, P., Falguères, C., Laurent, M., Toyoda, S., Bahain, J.J. \& Dolo, J.M. (2003): Artificial optical bleaching of the Aluminium centre in quartz implications to ESR dating of sediments. - Quaternary Science Reviews, 22: 1335-1338.

Voinchet, P., Bahain, J.J., Falguieres, C., Laurent, M., Dolo, J.M., Despriée, J., Gageonnet, R. \& Chausse, C. (2004): ESR dating of quartz extracted from Quaternary sediments: application to fluvial terraces systems of Northern France. - Quaternaire, 15: 135-141.

Voinchet, P., Falguères, C., Tissoux, H., Bahain, J.J., Despriée, J. \& Pirouelle, F. (2007): ESR dating of fluvial quartz: Estimate of the minimal distance transport required for getting a maximum optical bleaching. - Quaternary Geochronology, 2: 363-366.

Walther, R., Barabas, M. \& Mangini, A. (1992): Basic ESR studies on recent corals. - Quaternary Science Reviews, 11: 191-196.

Woda, C., Mangini, A. \& Wagner, G.A. (2001): ESR dating of xenolithic quartz in volcanic rocks. - Quaternary Science Reviews, 20: 993-998.

WodA, C. \& WAGNer, G.A. (2007): Non-monotonic dose dependence of the Ge- and Ti-centres in quartz. - Radiation Measurements, 42: 14411452.

Yé, Y., Diao, S., He, J., Gao, J. \& Lei, X. (1998): ESR dating studies of palaeo-debris-flow deposits in Dongchuan, Yunnan Province, China. - Quaternary Science Reviews, 17: 1073-1076.

Yin, G., Lin, M., Lu, Y., Li, J. \& Han, F. (2007): Preliminary ESR dating results on loess samples from the loess-paleosol sequence at Luochuan, Central Loess Plateau, China. - Quaternary Geochronology, 2: 381-385.

Yokoyama, Y., Falguères, C. \& Quaegebeur, J.P., 1985. ESR dating of quartz from Quaternary 
sediments: first attempt. - Nuclear Tracks and Radiation Measurements, 10: 921-928.

Zhao, J., Zhou, S., He, Y., Ye, Y. \& Liu, S. (2006):

ESR dating of glacial tills and glaciations in the Urumqi River headwaters, Tianshan Mountains, China. - Quaternary International, 144: 61-67.
Zhou, S., Wang, X., Wang, J. \& Xu, L. (2006): A preliminary study on timing of the oldest Pleistocene glaciation in Qinghai-Tibetan Plateau. - Quaternary International, 154-155: 44-51. 